\title{
Comparative genomic and transcriptomic analysis revealed genetic characteristics related to solvent formation and xylose utilization in Clostridium acetobutylicum EA 2018
}

Shiyuan $\mathrm{Hu}^{1,2}$, Huajun Zheng ${ }^{3}$, Yang Gu ${ }^{1,2}$, Jingbo Zhao ${ }^{1}$, Weiwen Zhang ${ }^{4}$, Yunliu Yang ${ }^{1,2}$, Shengyue Wang ${ }^{3}$, Guoping Zhao ${ }^{1,3}$, Sheng Yang ${ }^{1,2^{*}}$, Weihong Jiang ${ }^{1,2^{*}}$

\begin{abstract}
Background: Clostridium acetobutylicum, a gram-positive and spore-forming anaerobe, is a major strain for the fermentative production of acetone, butanol and ethanol. But a previously isolated hyper-butanol producing strain C. acetobutylicum EA 2018 does not produce spores and has greater capability of solvent production, especially for butanol, than the type strain C. acetobutylicum ATCC 824.

Results: Complete genome of C. acetobutylicum EA 2018 was sequenced using Roche 454 pyrosequencing. Genomic comparison with ATCC 824 identified many variations which may contribute to the hyper-butanol producing characteristics in the EA 2018 strain, including a total of 46 deletion sites and 26 insertion sites. In addition, transcriptomic profiling of gene expression in EA 2018 relative to that of ATCC824 revealed expressionlevel changes of several key genes related to solvent formation. For example, spoOA and adhEll have higher expression level, and most of the acid formation related genes have lower expression level in EA 2018. Interestingly, the results also showed that the variation in CEA_G2622 (CAC2613 in ATCC 824), a putative transcriptional regulator involved in xylose utilization, might accelerate utilization of substrate xylose.

Conclusions: Comparative analysis of C. acetobutylicum hyper-butanol producing strain EA 2018 and type strain ATCC 824 at both genomic and transcriptomic levels, for the first time, provides molecular-level understanding of non-sporulation, higher solvent production and enhanced xylose utilization in the mutant EA 2018. The information could be valuable for further genetic modification of $C$. acetobutylicum for more effective butanol production.
\end{abstract}

\section{Background}

High oil prices, growing concerns over national security and climate change are driving investment and innovation in the renewable alternative fuels [1,2]. Among various potentially alternatives, butanol has been proposed as an excellent substitute or supplement for gasoline, and has been demonstrated to work in some vehicles designed for use with gasoline without any engine modification [1]. In addition to manufacture from petroleum through chemical refinery process, industry production

\footnotetext{
* Correspondence: syang@sibs.ac.cn; whjiang@sibs.ac.cn

${ }^{1}$ Key Laboratory of Synthetic Biology, Institute of Plant Physiology and Ecology, Shanghai Institutes for Biological Sciences, Chinese Academy of Sciences, Shanghai 200032, China

Full list of author information is available at the end of the article
}

of butanol is typically through a so-called ABE fermentation process employing gram-positive, spore forming and anaerobic organism Clostridium acetobutylicum [2]. C. acetobutylicum is capable of producing a mixture of acetone (A), butanol (B) and ethanol (E) from a variety of carbohydrate substrates such as starch [3]. According to an estimate in 2008, butanol accounted for a 7-8.4 billon US dollar market worldwide and has a projected market expansion of 3\% per year in the near future [4].

Significant efforts have been spent on physiological and genetic characterization of solvent-producing C. acetobutylicum in the past decades [5-8], and tools for genetic manipulation of $C$. acetobutylicum were also developed [9-11]. In 2001, the whole genome of well studied C. acetobutylicum ATCC 824 was sequenced,
C Biomed Central

(c) 2011 Hu et al; licensee BioMed Central Ltd. This is an Open Access article distributed under the terms of the Creative Commons Attribution License (http://creativecommons.org/licenses/by/2.0), which permits unrestricted use, distribution, and reproduction in any medium, provided the original work is properly cited. 
revealing a $3.94 \mathrm{Mb}$ chromosome which encodes 3740 open reading frames (ORF), and a $192 \mathrm{~Kb}$ megaplasmid which encodes 178 ORFs [12]. Afterwards, a series of studies employing global approaches have been performed [13-16], and the genome-scale metabolic model of C. acetobutylicum was also constructed [17-19]. These efforts have improved the understanding of regulatory and metabolic networks of this industry significant species.

However, most of the C. acetobutylicum strains are not optimized systems for butanol production because their spore-forming life cycle decreases the efficiency of industrial fermentation, and the ABE fermentation process also creates a number of by-products, such as $\mathrm{H}_{2}$, acetic, lactic and propionic acids, acetone, isopropanol and ethanol [20]. As a result, the butanol yield is difficult to control and a significant amount of energy is wasted in these by-products. Moreover, it also increases the cost of downstream butanol purification. To address these issues, various modification approaches, such as mutagenesis by chemical or radiation agents, and genetic engineering, have been performed to improve the butanol production [10,21]. Our laboratory has previously obtained a high butanol producing strain, C. acetobutylicum EA 2018, through butanol resistance screening of $N$-methyl- $N$-nitro- $N$-nitrosoguanidine (NTG) treated Clostridium strain isolated from soil [22]. Preliminary results in a 100-ton continuous fermenter showed that butanol ratio and starch conversion rates of EA 2018 strain were $10 \%$ and 5\% higher than those reported in recent literature [23]. To explore the genetic difference between EA 2018 and ATCC 824, in this study, the C. acetobutylicum EA 2018 genome was sequenced using Roche 454 pyrosequencing together with traditional Sanger sequencing. In addition, comparative genomic and transcriptomic analyses of EA 2018 and ATCC 824 were also performed. The study, for the first time, provides a molecular-level understanding of higher solvent production, enhanced xylose utilization and non-sporulation in the mutant EA 2018. The information could be valuable for further genetic modification of $C$. acetobutylicum for more effective butanol production.

\section{Results and Discussion Characterization of isolate EA 2018}

The original solvent producing strain was isolated by our laboratory previously [22]. After several rounds of mutagenesis using NTG ( $N$-methyl- $N$ '-nitro- $N$-nitrosoguanidine), we obtained a hyper butanol-producing strain designated as EA 2018. This strain was later identified as Clostridium acetobutylicum by the China Center for Type Culture Collection (CCTCC) and was kept in CCTCC under the preservation No. CCTCC
M_94061. In this work, the $16 \mathrm{~S}$ rDNA of C. acetobutylicum EA 2018 was cloned and sequenced. The 1399 bp 16S rDNA sequence of C. acetobutylicum EA 2018 was $100 \%$ identical to that of the type strain C. acetobutylicum ATCC 824 (Accession number NC_003030 for ATCC 824 genome sequence) [12]. Furthermore, the sol operon involved in butanol production was also cloned from C. acetobutylicum EA 2018 and sequenced, the comparative analysis showed that the sol operon of C. acetobutylicum EA 2018 was also $100 \%$ identical to that of C. acetobutylicum ATCC 824 (Accession number NC_001988 for ATCC 824 megaplasmid sequence) [24]. The analysis demonstrated that EA 2018 and ATCC 824 belong to the same species.

Fermentation experiments were performed to compare the solvent production patterns of $C$. acetobutylicum EA 2018 and ATCC 824. EA 2018 exhibited higher solvent formation capacity than ATCC 824 strain in either $6 \%(w / v)$ glucose or xylose media (Figure 1A, B). After $48 \mathrm{~h}$ fermentation, $8.3 \mathrm{~g} / \mathrm{L}$ glucose remained in the EA 2018 culture, while $16.5 \mathrm{~g} / \mathrm{L}$ glucose still remained in the ATCC 824 culture after $72 \mathrm{~h}$ fermentation (Figure 1A). After $96 \mathrm{~h}$ fermentation, $23.6 \mathrm{~g} / \mathrm{L}$ xylose was present in the EA 2018 culture, while $35.7 \mathrm{~g} / \mathrm{L}$ xylose was still remained in the ATCC 824 culture (Figure 1B). In most C. acetobutylicum strains, solvent formation is always coupled with initiation of sporulation [10]. However, after fermentation of $72 \mathrm{~h}$, there was no spore found in EA 2018 cultures, while significant spores were found in ATCC 824. With its higher solvent production and non-spore forming characteristics, EA 2018 strain could be an excellent strain for industrial application.

\section{Overview of C. acetobutylicum EA 2018 genome}

For better understanding of the genetic basis of improved butanol producing characteristics in EA 2018, the whole genome of EA 2018 was sequenced. The genome has a circular chromosome consisting of 3,940,230 bp with an average $\mathrm{G}+\mathrm{C}$ content of $30.93 \%$ and a circular megaplasmid of 191,996 bp with an average $\mathrm{G}+\mathrm{C}$ content of $30.91 \%$. The genome finishing procedures were listed in Additional file 1, 2, 3. A total of 3923 protein coding sequence (CDS) including 3,746 in chromosome and 176 in megaplasmid were indentified in the EA 2018 genome, representing 86.8\% of the genome and $83.8 \%$ of the megaplasmid, respectively. The functional classification of all EA 2018 genes was listed in Table 1 . There are 11 copies of rDNA operons and a total of 75 tRNA genes scattered over the EA 2018 genome. Genomic comparison with type strain ATCC 824 revealed the highly conserved gene content and gene order between these two strains. The base numbering 


\section{A}

Acetone

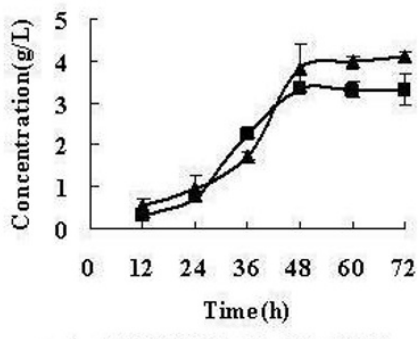

$\rightarrow$ ATCC $824 \rightarrow-$ EA 2018

Acetate

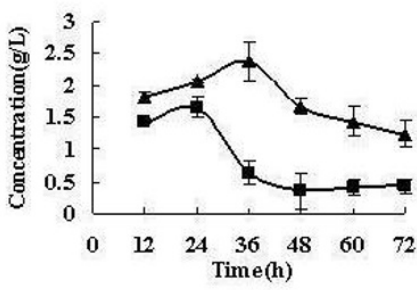

$\rightarrow \mathrm{ATCC} 824 \rightarrow-\mathrm{EA} 2018$

B

Acetone

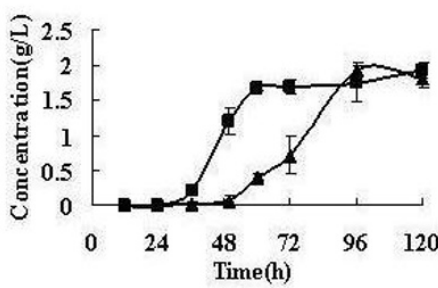

$\multimap \mathrm{ATCC} 824 \rightarrow-\mathrm{EA} 2018$

Acetate

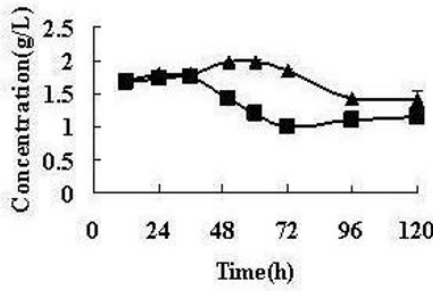

$\leftarrow$ ATCC $824-\square-E A 2018$
Ethanol

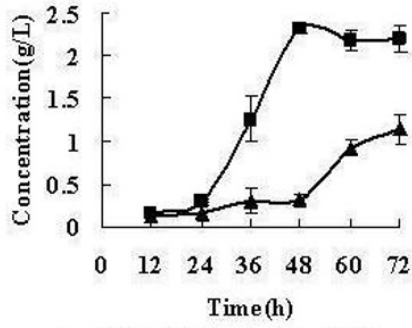

$\rightarrow$ ATCC $824 \rightarrow-$ EA 2018

Butyrate

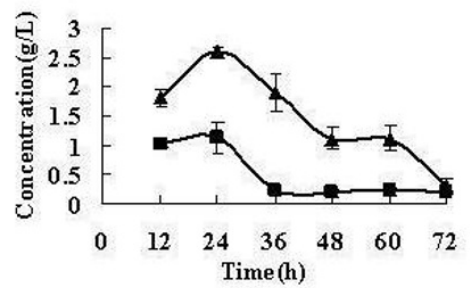

$\leftarrow$ ATCC $824 \rightarrow-$ EA 2018

Ethanol

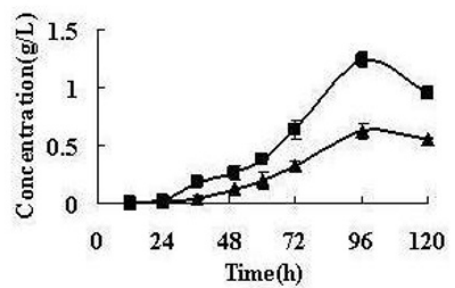

$\rightarrow$ ATCC $824 \rightarrow-$ EA 2018

Butyrate

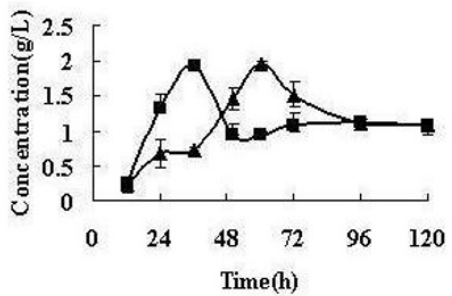

$\multimap$ ATCC $824 \rightarrow-$ EA 2018
Butanol

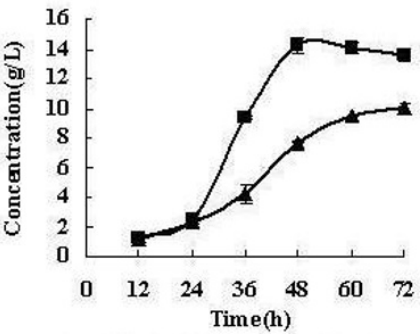

$\rightarrow \mathrm{ATCC} 824 \rightarrow-\mathrm{EA} 2018$

Gluc ose

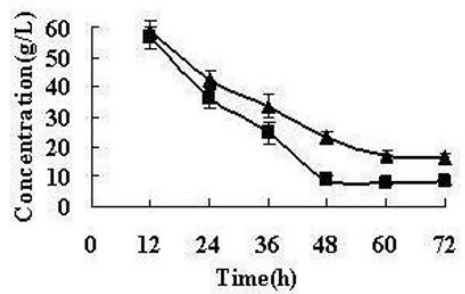

$\rightarrow$ ATCC $824 \rightarrow-$ EA 2018

Butanol

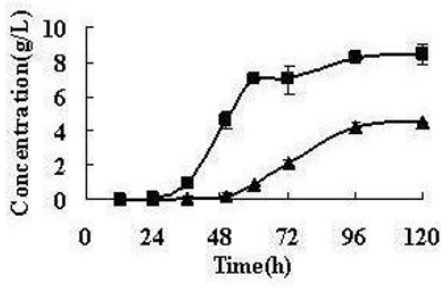

$\rightarrow$ ATCC $824-$-EA 2018

Xylose

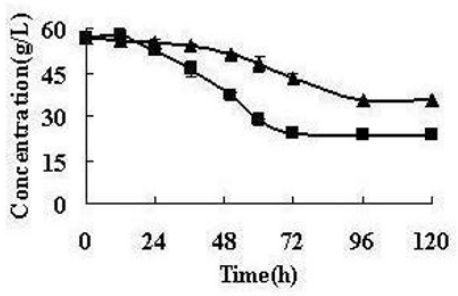

$\rightarrow$ ATCC $824 \rightarrow-E A 2018$

Figure 1 Solvent and acid production, sugar utilization of C. acetobutylicum EA 2018 versus C. acetobutylicum ATCC 824 in P2 medium contained with $6 \%$ glucose (A) and $6 \%$ xylose (B). 
Table 1 Function Classification of EA 2018 genes

\begin{tabular}{|c|c|c|c|c|c|}
\hline Function & $\begin{array}{l}\text { Numbers in } \\
\text { plasmid }\end{array}$ & $\begin{array}{l}\text { Numbers in } \\
\text { genome }\end{array}$ & Function & $\begin{array}{l}\text { Numbers in } \\
\text { plasmid }\end{array}$ & $\begin{array}{l}\text { Numbers in } \\
\text { genome }\end{array}$ \\
\hline $\begin{array}{l}\text { Energy production and } \\
\text { conversion }\end{array}$ & 12 & 121 & Cell envelope biogenesis, outer membrane & 10 & 182 \\
\hline $\begin{array}{l}\text { Cell division and chromosome } \\
\text { partitioning }\end{array}$ & 3 & 38 & Cell motility and secretion & 1 & 92 \\
\hline $\begin{array}{l}\text { Amino acid transport and } \\
\text { metabolism }\end{array}$ & 1 & 212 & $\begin{array}{l}\text { Posttranslational modification, protein } \\
\text { turnover, chaperones }\end{array}$ & 2 & 78 \\
\hline $\begin{array}{l}\text { Nucleotide transport and } \\
\text { metabolism }\end{array}$ & 1 & 73 & Inorganic ion transport and metabolism & 6 & 93 \\
\hline $\begin{array}{l}\text { Carbohydrate transport and } \\
\text { metabolism }\end{array}$ & 22 & 221 & $\begin{array}{l}\text { Secondary metabolites biosynthesis, } \\
\text { transport and catabolism }\end{array}$ & 3 & 27 \\
\hline Coenzyme metabolism & 1 & 110 & General function prediction only & 16 & 321 \\
\hline Lipid metabolism & 6 & 76 & Function unknown & 5 & 258 \\
\hline $\begin{array}{l}\text { translation,ribosomal structure } \\
\text { and biogenesis }\end{array}$ & 0 & 159 & Signal transduction mechanisms & 4 & 126 \\
\hline transcription & 22 & 243 & Intracellular trafficking and secretion & 0 & 14 \\
\hline \multirow{2}{*}{$\begin{array}{l}\text { DNA replication, recombination } \\
\text { and repair }\end{array}$} & 5 & 137 & Defense mechanisms & 5 & 106 \\
\hline & & & Not in this system & 55 & 1059 \\
\hline
\end{tabular}

start point of EA 2018 were chosen as the same site in ATCC 824 (Figure 2).

\section{Comparative genomic analysis of EA 2018 and ATCC 824}

The size of the EA 2018 chromosome is $650 \mathrm{bp}$ smaller than that of ATCC 824, and the size of the EA 2018 megaplasmid is 4 bp smaller than that of ATCC 824 . Compared with ATCC 824, a total of 46 deletion sites and 26 insertion sites were found across the EA 2018 genome, including 1 deletion site in the megaplasmid (Additional file 4). Among them, 55 sites are single nucleotide indel (i.e. insertion or deletion), and only 7 indel sites are larger than $100 \mathrm{bp}$. The largest insertion is $1768 \mathrm{bp}$ in $1276337-1278091$ which is located within a hypothetical protein gene (CEA_G1125, corresponding to CAC1113 in ATCC 824), while the largest deletion is 1812 bp in 1112030-1112031 which is located within a predicted member protein gene (CEA_G0978, corresponding to CAC0966 in ATCC 824). Apart from those indels, 440 single nucleotide variations (SNVs) were identified between the two chromosomes, and 11 SNVs were identified between the megaplasmid of EA 2018 and ATCC 824 (Additional file 5). The 523 variations (including 72 indels and 451 SNVs) affected a total of 229 protein encoding genes (including 10 genes in megaplasmid) and 38 predicted promoters (including 1 in megaplasmid) in the EA 2018 genome. Excluding the synonymous substitution, a total of 189 proteins had amino acids changes, while 47 of those proteins were with similar amino acid variations (Additional file 6). The 38 genes with their putative promoters affected were listed in Additional file 7. In Table 2 and 3, variations within putative promoters and genes related to solvent formation, xylose utilization, and spore formation (i.e. three key aspects related to enhanced butanol production in EA 2018) were listed.

\section{Comparative transcriptomic analysis of EA 2018 and ATCC 824}

To further explore the molecular mechanism of enhanced butanol production in the EA 2018 strain, DNA microarray of $C$. acetobutylicum were manufactured and used for a comparative analysis between EA 2018 and ATCC 824. The complete set of DNA array data was available in Additional file 8. Microarray analysis showed that a total of 2215 genes were differentially regulated at transcriptional level in at least 1 cultivation time point. Among them, differentially regulated genes related to some important metabolic pathways were listed in Table 4. And some putative promoter variation genes such as adhEII were found with differential expression level in the EA 2018 strain (Table 5). The detailed comparative analysis of transcriptomic data, along with genomic data (i.e. variation gene sequence) and biochemical phenotypes will be provided below from three key aspects related to enhanced butanol production (i.e. solvent formation, xylose utilization, and spore formation).

\section{Changes in expression of adhEIl, spoOA and hydrogenase gene may contribute to enhanced solvent formation in EA 2018}

Comparative genomic analysis identified a set of solventrelevant genes with variations within their coding sequences (Table 2). And most of which were SNV variations, such as genes encoding phosphotransacetylase 


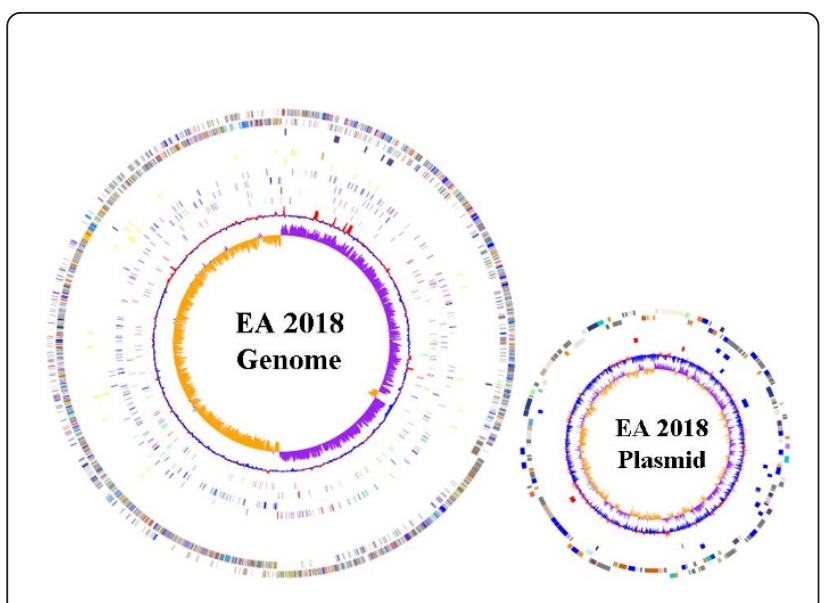

Figure 2 Atlas of the chromosome and the megaplasmid of $C$. acetobutylicum EA 2018 and its comparison with C. acetobutylicum ATCC 824. Moving inside, each concentric circle represents genomic data for C. acetobutylicum EA 2018 and its comparison with C. acetobutylicum ATCC 824. For chromosome atlas, the outer circle illustrates predicted coding sequences on the plus and minus strands, respectively, colored by functional categories according to COG classification. The 2 nd circle represents EA 2018 variation genes compared with ATCC 824. The 3rd circle displays IS elements in EA 2018. The 4th circle shows rDNA genes in EA 2018, distinguished by plus strand (gold) and minus strand (red). The 5th circle shows tRNA genes in EA 2018, distinguished by plus strand (pink) and minus strand (blue). The 6th circle represent GC content, red for GC content above average and blue for $\mathrm{GC}$ content below average. The 7th circle (innermost) represents GC skew (G-C)/ $(\mathrm{G}+\mathrm{C})$ calculated using a $100 \mathrm{~kb}$ window. For megaplasmid atlas, the outer circle illustrates predicted coding sequences on the plus and minus strands, respectively, colored by functional categories according to COG classification. 2nd circle represents EA 2018 variation genes compared with ATCC 824. 3th circle represent GC content, red for GC content above average and blue for GC content below average. The 4th circle (innermost) represents $\mathrm{GC}$ skew (G-C)/ $(\mathrm{G}+\mathrm{C})$ calculated using a $100 \mathrm{~kb}$ window.

and acetyl-CoA acetyltransferase. In addition, comparative genomics analysis also identified some variations up-stream of solvent-relevant genes (Table 3), which could potentially affect expression level of these genes. For example, a SNV site was found 84 bases upstream of the start codon of the AdhEII encoded gene CEA_P0034 (CA_P0035 in ATCC 824), under the $s_{1}$ transcription start point [25]. Consistent with the variations at genomic level, we also found that transcription level of solvents formation genes, such as adhEII were highly expressed in EA 2018 relative to ATCC 824 (Table 5 and Figure 3).

Spo0A is a central regulator of sporulation and solvent formation in C. acetobutylicum. Previous studies showed that $C$. acetobutylicum spoOA inactivation mutant stops producing spores and solvent, while over-expression of spoOA gene can enhance solvent production since $0 \mathrm{~A}$ binding boxes have been identified in the promoter regions of solvent formation genes [26]. Therefore, it is speculative that the higher expression of spoOA could be one of the reasons for the higher butanol formation in EA 2018. Comparative transcriptomic analysis confirmed our speculation that higher transcriptional level of $s p o 0 A$ was found in EA 2018 (Table 4 and Figure 3). There were three ways for Spo0A to be phosphorylated (i.e. by a sensory kinase; through a novel phosphorylation system; by butyryl-P or acetyl-P) [27]. Using trans-membrane domain along with transcriptional analysis, four orphan kinases (CAC0437, CAC0323, CAC0903, and CAC2730) were identified as plausible kinases that might phosphorylate Spo0A in B. subtilis [27]. In our study, we also found that the transcriptional level of an orphan kinase CEA_G0344 (corresponding to CAC0323 in ATCC 824) was higher in EA 2018 (Figure 3), and the result is consistent well with the $5 p o 0 A$ gene expression data.

During solvent fermentation process in C. acetobutylicum, a considerable amount of NADH was consumed by hydrogenase via reduced $\mathrm{Fd}\left(\mathrm{FeH}_{2}\right)$ to form hydrogen [28]. Previous reports showed that butanol production by $C$. acetobutylicum can be elevated by inhibiting hydrogen formation through adding viologen dyes or increasing hydrogen partial pressure [28], and knockdown of hupCBA cluster which encoded hydrogen uptake genes in C. saccharoperbutylacetonicum strain N1-4 decreased butanol formation (to $75.6 \%$ compared to the control strain) successfully [29]. Biochemical analysis showed that hydrogen formation in EA 2018 was nearly $29 \%$ lower than in ATCC 824 (Table 6). Interestingly, comparative genomic analysis also revealed SNVs in NiFe-hydrogenase coded gene CEA_P0140 (CA_P0141 in ATCC 824) and in the promoter of Fe-only hydrogenase coded gene CEA_G0028 (CAC 0028 in ATCC 824) (Table 2, 3). The variation site of CEA_G 0028 was located on the $12^{\text {th }}$ base upstream of the start codon of hydA and altered the ribosome binding site (RBS) of this important gene (GGGAGG in ATCC 824 versus AGGAGG in EA 2018). In addition, the higher expression level of hydrogen uptake genes $m b h s$ and $m b h l$ were also revealed in EA 2018 (Figure 3). The result showed that hydrogen uptake could be an important factor for butanol formation, and increased expression level of hydrogen uptake gene $m b h s$ and $m b h l$ was closely correlated to the lower hydrogen formation in EA 2018, which can eventually help balance the NAD $(\mathrm{P}) \mathrm{H}$ needed for higher production of butanol.

Using non-replicating plasmid $\mathrm{pO} 1 \mathrm{X}$, putative solvent formation repressor solR gene was inactivated in ATTC 824 , and its fermentation experiment revealed that more solvent were produced in the solR inactivation mutant [5]. Although there are different speculations on the function of SolR [25], it has been confirmed that low expression of 
Table 2 EA 2018 gene variations associated with key phenotypes

\begin{tabular}{|c|c|c|c|c|c|c|}
\hline $\begin{array}{l}\text { Gene locus } \\
\text { in EA } 2018\end{array}$ & $\begin{array}{l}\text { Gene locus } \\
\text { in ATCC } 824\end{array}$ & $\begin{array}{l}\text { Gene variation } \\
\text { sites in EA } 2018\end{array}$ & $\begin{array}{l}\text { Gene variation } \\
\text { sites in ATCC } 824\end{array}$ & $\begin{array}{l}\text { Protein variation } \\
\text { sites in EA } 2018\end{array}$ & $\begin{array}{l}\text { Protein variation } \\
\text { sites in ATCC } 824\end{array}$ & Product name \\
\hline \multicolumn{7}{|c|}{ Solvent formation related genes } \\
\hline CEA_G1048 & CAC1036 & $899(T)$ & $899(C)$ & $300(V)$ & $300(A)$ & Pyruvate kinase \\
\hline CEA_G1755 & CAC1742 & $391(A)$ & $391(\mathrm{G})$ & $131(\mathrm{~N})$ & $131(\mathrm{D})$ & phosphotransacetylase \\
\hline CEA_G2463 & CAC2449 & $256(A)$ & $256(G)$ & $86(S)$ & $86(\mathrm{G})$ & Predicted flavoprotein \\
\hline CEA_G2485 & CAC2471 & 439(A) & 438-439(-) & $147-150(R, L, P, I)$ & $\begin{array}{l}\text { 147-150 (G,C,L,Stop } \\
\text { codon) }\end{array}$ & $\begin{array}{l}\text { Transcriptional regulator, TetR/ } \\
\text { AcrR family }\end{array}$ \\
\hline CEA_G2556 & CAC2543 & $\begin{array}{l}241-249(G, T, A, G, \\
A, T, C, A, T)\end{array}$ & $240-241(-)$ & $81-83(V, D, H)$ & $80-81(-)$ & $\begin{array}{l}\text { Electron-transferring } \\
\text { flavoprotein large subunit }\end{array}$ \\
\hline CEA_G2806 & CAC2798 & $286(A)$ & $286(G)$ & $96(M)$ & $96(V)$ & NADH:flavin oxidoreductase \\
\hline CEA_P0058 & CA_P0059 & 754(A) & $754(C)$ & $252(N)$ & $252(H)$ & Alcohol dehydrogenase \\
\hline CEA_P0077 & CA_P0078 & $91(A)$ & $91(\mathrm{G})$ & $31(T)$ & $31(A)$ & acetyl-CoA acetyltransferase \\
\hline CEA_P0140 & CA_P0141 & $566(T)$ & $566(C)$ & 189(I) & 189(T) & $\begin{array}{l}\text { Periplasmic hydrogenase small } \\
\text { subunit, dehydrogenase }\end{array}$ \\
\hline \multicolumn{7}{|c|}{ Substrate utilization related genes } \\
\hline CEA_G0239 & CAC0234 & 1072(T) & $1072(C)$ & 358(Stop codon) & $358(Q)$ & $\begin{array}{l}\text { PTS system, fructoso-specific } \\
\text { IIBC component }\end{array}$ \\
\hline CEA_G1333 & CAC1319 & $5(\mathrm{~T})$ & $5(C)$ & $2(l)$ & $2(T)$ & $\begin{array}{l}\text { Glycerol uptake facilitator } \\
\text { protein, GLPF }\end{array}$ \\
\hline CEA_G1472 & CAC1456 & $974(T)$ & $974(A)$ & $325(\mathrm{M})$ & $325(K)$ & $\begin{array}{l}\text { Sugar-binding periplasmic } \\
\text { protein }\end{array}$ \\
\hline CEA_G2622 & CAC2613 & $270(T)$ & $270(G)$ & $90(C)$ & $90(\mathrm{~W})$ & $\begin{array}{l}\text { Transcriptional regulators of } \\
\text { NagC/XylR family }\end{array}$ \\
\hline CEA_G2919 & CAC2912 & $97(A)$ & $97(C)$ & $33(T)$ & $33(P)$ & $\begin{array}{l}\text { Sugar-binding periplasmic } \\
\text { protein }\end{array}$ \\
\hline CEA_P0052 & CA_P0053 & $317(C)$ & $317(T)$ & $106(P)$ & $106(L)$ & $\begin{array}{l}\text { Xylanase, glycosyl hydrolase } \\
\text { family } 10\end{array}$ \\
\hline \multicolumn{7}{|c|}{ Sporulation related genes } \\
\hline CEA_G0080 & CAC0080 & $1160(A)$ & $1159-1160(-)$ & $\begin{array}{l}\text { 387-392(N,I,Q,D,L, } \\
\text { Stop codon) }\end{array}$ & 387-391 (I,Y,K,I,Y,K) & Histidine kinase-like ATPase \\
\hline CEA_G0656 & CAC0644 & $1226(\mathrm{~T})$ & $1226(G)$ & $409(\mathrm{~V})$ & 409(G) & $\begin{array}{l}\text { Spore germination protein } \\
\text { gerKA }\end{array}$ \\
\hline CEA_G0710 & CAC0699 & $416(C)$ & $416(T)$ & 139(T) & $139(1)$ & Spore photoproduct lyase, splB \\
\hline CEA_G2066 & CAC2052 & $688(A)$ & 687-688(-) & $\begin{array}{l}\text { 230-248 (18 amino } \\
\text { acid) }\end{array}$ & $\begin{array}{l}\text { 230-238 (7 amino acid } \\
\text { and a Stop Codon) }\end{array}$ & $\begin{array}{l}\text { DNA-dependent RNA } \\
\text { polymerase sigma subunit }\end{array}$ \\
\hline CEA_G3736 & CAC3729 & $374(T)$ & $374(C)$ & $125(\mathrm{~L})$ & $125(P)$ & $\begin{array}{l}\text { Stage } 0 \text { sporulation J, ParB } \\
\text { family of DNA-binding proteins }\end{array}$ \\
\hline CEA_P0016 & CA_P0017 & $11,245(G, A)$ & $11,245(T, C)$ & $4,82(\mathrm{E}, \mathrm{G})$ & $4,82(A, V)$ & $\begin{array}{l}\text { Spore germination protein, } \\
\text { GRKB }\end{array}$ \\
\hline CEA_P0019 & CA_P0020 & $1120(C)$ & $1120(\mathrm{~T})$ & 407(A) & $407(V)$ & $\begin{array}{l}\text { Spore germination protein, } \\
\text { GRKA }\end{array}$ \\
\hline CEA_P0021 & CA_P0022 & $-151(T)$ & $104(C)$ & $1(-)$ & $\begin{array}{l}\text { 1-85(85 amino acids } \\
\text { insertion) }\end{array}$ & $\begin{array}{l}\text { Spore germination protein, } \\
\text { GRKB }\end{array}$ \\
\hline
\end{tabular}

Numbers in gene or protein variation sites lines indicated the variation sites in genes; the letters in bracket means the corresponding variation bases or amino acid; the symbol "-" means deletion in genes; the symbol "—" means consecutive deletion in genes; "No" means no amino acid variation; "Stop codon" means this site is mutated to stop codon.

solR will enhance solvent formation [26]. Transcriptomic analysis revealed a lower expression level of $s o l R$, especially in the solventogenic phase in EA 2018, which might be related to hyper-butanol formation (Figure 3 ).

It has been suggested that the onset of solvent production is closely related to the accumulation of acid end products [30], and the addition of acetate and butyrate might result in a rapid induction of solventogenesis [31]. For example, it was reported that the concentration of undissociated butyric acid might play an important role in the induction of solventogenesis [32]. Transcriptomic analysis showed that expression of $a c k, p t a, b u k$ and $p t b$ were all lower in EA 2018 than in ATCC 824 (Figure 3), consistent with the biochemical analysis (Figure 1). In addition, the results also suggested that the transition to the solventogenesis took place at a lower acetate and butyrate acid concentration in EA 2018 compared to ATCC 824. 
Table 3 EA 2018 putative promoter variations related to key phenotypes

\begin{tabular}{|c|c|c|c|c|}
\hline $\begin{array}{l}\text { Gene locus in EA } \\
2018\end{array}$ & $\begin{array}{l}\text { Gene locus in } \\
\text { ATCC } 824\end{array}$ & $\begin{array}{l}\text { Gene variation sites in } \\
\text { EA } 2018\end{array}$ & $\begin{array}{l}\text { Gene variation sites in } \\
\text { ATCC } 824\end{array}$ & Product Name \\
\hline \multicolumn{5}{|c|}{ Solvent formation related genes } \\
\hline CEA_G0028 & CAC0028 & $-12(\mathrm{~T})$ & $-12(C)$ & Hydrogen dehydrogenase \\
\hline CEA_P0034 & CA_P0035 & $-84(T)$ & $-84(C)$ & Aldehyde-alcohol dehydrogenase, ADHEII \\
\hline \multicolumn{5}{|c|}{ Substrate utilization related genes } \\
\hline CEA_G3043 & CAC3037 & $-80(\mathrm{~T})$ & $-80(C)$ & $\begin{array}{l}\text { Catabolite control protein, Lacl family } \\
\text { transcriptional regulator }\end{array}$ \\
\hline CEA_G3455 & CAC3451 & $-84(\mathrm{~T})$ & $-84(G)$ & Sugar/Na+(H+) simporter \\
\hline CEA_G1086 & CAC1075 & $-56(T)$ & $-56(G)$ & Beta-glucosidase family protein \\
\hline CEA_G1365 & CAC1351 & $-97(T)$ & $-97(C)$ & Periplasmic sugar-binding protein \\
\hline \multicolumn{5}{|c|}{ Sporulation related genes } \\
\hline CEA_G1634 & CAC1620 & $-136(T)$ & $-136(G)$ & Small acid-soluble spore protein \\
\hline CEA_G3742 & CAC3735 & $-(8-7)(-)$ & $-7(C)$ & $\begin{array}{l}\text { Predicted RNA-binding protein Jag, SpollIJ- } \\
\text { associated }\end{array}$ \\
\hline
\end{tabular}

Numbers in gene or protein variation sites lines indicated the variation sites in genes; the letters in bracket means the corresponding variation bases or amino acid; the symbol "-" means deletion in genes.

\section{Analysis of substrate utilization genes and inactivation of CAC2613 revealed genetic bases of better xylose utilization in EA 2018}

Solvent production from agriculturally based lignocellulosic substrates (i.e. cellulose or hemicellulose) was studied previously and results showed that a large part of the lignocellulosic substrates were hydrolyzed into glucose and xylose [33]. Therefore, utilization of these substrates, especially xylose, can be important in determining the efficiency of solvent production. Comparative genomic analysis identified several mutations in the putative promoters and within the coding region of genes which might be involved in substrates utilization (Table 2, 3). Among them, three out of seven mutated genes encode sugar-binding periplasmic proteins. One interesting gene was CEA_G2622 (CAC2613 in ATCC 824 ), which encodes a transcriptional regulator of NagC/XylR family and the sequence variation could cause a putative W90C substitution. The gene is located on the upstream of $x y l B$ (xylulose kinase) gene (Figure $4 \mathrm{~A})$. Since most of the known $x y l R$ genes in other ATrich gram-positive species such as B. subtillus and C. difficile were located upstream of $x y l$ operon [34,35], we speculated that this gene (CEA_G2622) may function similarly as $x y l R$ in EA 2018 (Figure 4B). Transcriptomic analysis showed that even in the glucose-based medium, the expression level of $x y l B$ was higher in EA 2018 (Figure 3). However, evidence is still needed to confirm the direct regulatory function of CEA_G2622 on $x y l$ operon. To do so, we disrupted CAC2613 gene in C. acetobutylicum ATCC 824 (corresponding to CEA_G2622 in EA 2018) using Targetron system (Figure 4C). Batch fermentation showed that xylose utilization in CAC2613 disrupted mutant was faster than ATCC 824 (constant $\mathrm{pH}$ 5.0). In addition, the time of butanol formation and acids reassimilation in the mutant were $24 \mathrm{~h}$ earlier than ATCC 824 strain, although the final concentration of end products and xylose were nearly the same (Figure 4D). The similarities, in terms of the time of butanol formation and acid reassimilation, between EA 2018 and the CAC2613 disrupted ATCC 824 derived mutant, suggested that better xylose utilization in EA 2018 could be related to the mutation in CEA_G2622 (CAC2613 in ATCC 824).

Previous study showed that ATCC 824 harbors extracellular and cell bound xylanase activities when grown under xylose or glucose-based media, and most of the putative xylanase encoded genes were located on the megaplasmid [36]. Two endoxylanase genes, thermostable xylanase 10A gene (CA_P0053 in ATCC 824 and CEA_P0052 in EA 2018) and xylanase 10B gene (CA_P0116 in ATCC 824 and CEA_P0115 in EA 2018) located on mega-plasmid were identified in EA 2018 [37]. In addition, transcriptomic analysis showed higher expression level of those two genes in EA 2018 (Figure 5). Xylan is the major component of hemicelluloses. The higher expression level of xylanase in EA 2018 could make it suitable for hemicellulosic fermentation, and could offer potential economic benefits in the future [1].

Among all putative promoter variations, there were 4 sites which may affect substrate utilization in EA 2018 (Table 3). Among them, CEA_G3043 (CAC3037 in ATCC 824) gene that encodes a catabolite control protein (CcpA) has a variation site located on 80 bp upstream of the start codon. CcpA play an important role in catabolite repression and inactivation of this gene will release catabolic repression in many grampositive organisms $[8,38,39]$. However, no significant regulation was observed for the expression level of CcpA gene in EA 2018, and the potential effect of the 
Table 4 List of differentially regulated genes in key functional groups

\begin{tabular}{|c|c|c|c|c|c|c|c|c|}
\hline $\begin{array}{l}\text { Gene } \\
\text { locus in } \\
\text { EA } 2018\end{array}$ & $\begin{array}{l}\text { Gene } \\
\text { locus in } \\
\text { ATCC } 824\end{array}$ & $\begin{array}{r}9 \mathrm{~h} \\
\left(\log _{2} \text { Ratio }\right. \\
2018 / 824) \\
\end{array}$ & $\begin{array}{r}13 \mathrm{~h} \\
\left(\log _{2} \text { Ratio }\right. \\
2018 / 824) \\
\end{array}$ & $\begin{array}{r}17 \mathrm{~h} \\
\left(\log _{2} \text { Ratio }\right. \\
2018 / 824) \\
\end{array}$ & $\begin{array}{r}21 \mathrm{~h} \\
\left(\log _{2} \text { Ratio }\right. \\
2018 / 824) \\
\end{array}$ & $\begin{array}{r}24 \mathrm{~h} \\
\left(\log _{2} \text { Ratio }\right. \\
2018 / 824) \\
\end{array}$ & $\begin{array}{r}30 \mathrm{~h} \\
\left(\log _{2} \text { Ratio }\right. \\
2018 / 824) \\
\end{array}$ & Product Name \\
\hline \multicolumn{9}{|c|}{ Carbohydrate transportant and metabolism } \\
\hline CEA_G0343 & CA_C0332 & -2.97436 & -3.22501 & -2.37758 & -2.08064 & -2.57556 & -1.49158 & Beta-mannanase \\
\hline CEA_G0501 & CA_C0490 & 2.331505 & 2.410311 & 2.244172 & 2.361906 & 2.703307 & 2.474026 & $\begin{array}{l}\text { sugar kinase, N-terminal region - } \\
\text { uncharacterized protein }\end{array}$ \\
\hline CEA_G0552 & CA_C0539 & -3.20909 & -3.00324 & -2.93013 & -2.29917 & -3.34939 & -3.01922 & $\begin{array}{l}\text { ChW repeat-containing mannanase } \\
\text { ManB }\end{array}$ \\
\hline CEA_G0553 & CA_C0540 & -3.097 & -3.03398 & -2.7227 & -2.28306 & -3.3665 & -2.72934 & $\begin{array}{l}\text { ChW repeat-containing mannanase } \\
\text { ManB }\end{array}$ \\
\hline CEA_G1677 & CA_C1664 & 1.744408 & 2.013214 & 2.53088 & 1.134795 & 1.816259 & 2.062687 & glycogen phosphorylase \\
\hline CEA_G2012 & CA_C1997 & 3.052977 & 3.503142 & 3.004392 & 2.8712 & 2.075025 & 1.372718 & glycosyltransferase \\
\hline CEA_G2022 & CA_C2007 & 3.179932 & 3.308867 & 2.812136 & 2.509044 & 1.656072 & 1.958591 & glycosyltransferase \\
\hline CEA_G2528 & CA_C2514 & 2.588809 & 2.748177 & 3.625871 & 4.329215 & 2.708288 & 1.042021 & Beta galactosidase \\
\hline CEA_G2815 & CA_C2807 & 2.40568 & 2.124155 & 2.476058 & 2.653992 & 2.808752 & 1.737289 & $\begin{array}{l}\text { endo-1,3(4)-beta-glucanase family } \\
\text { protein } 16\end{array}$ \\
\hline CEA_G2818 & CA_C2810 & 1.835243 & 2.287891 & 2.800041 & 3.929157 & 3.739976 & 4.256289 & glucoamylase family protein \\
\hline CEA_G3051 & CA_C3045 & -2.41601 & -2.05151 & -2.19775 & -2.37262 & -2.3321 & -2.16444 & PHP family hydrolase \\
\hline CEA_G3060 & CA_C3054 & -3.63818 & -4.38617 & -4.64833 & -5.02922 & -5.12371 & -3.50751 & phosphoheptose isomerase \\
\hline CEA_G3426 & CA_C3422 & -1.07396 & -2.79221 & -3.22016 & -2.15086 & -2.69786 & -1.37931 & sugar:proton symporter (xylulose) \\
\hline CEA_P0052 & CA_P0053 & 2.477697 & 2.868013 & 3.649329 & 3.695172 & 3.721454 & 5.987476 & xylanase \\
\hline CEA_P0053 & CA_P0054 & 4.25084 & 2.735168 & 2.447001 & 3.424303 & 3.598697 & 5.185082 & $\begin{array}{l}\text { xylanase/chitin deacetylase family } \\
\text { protein }\end{array}$ \\
\hline CEA_P0065 & CA_P0066 & 3.062167 & 1.145145 & 2.159875 & 4.902259 & 3.81378 & 2.953822 & $\begin{array}{l}\text { mannose-specific } \\
\text { phosphotransferase system } \\
\text { component } \| A B\end{array}$ \\
\hline CEA_P0066 & CA_P0067 & 2.925021 & 1.579742 & 2.174524 & 4.883877 & 3.683632 & 2.826095 & $\begin{array}{l}\text { mannose/fructose-specific } \\
\text { phosphotransferase system } \\
\text { component IIC }\end{array}$ \\
\hline CEA_P0067 & CA_P0068 & 3.006142 & 1.74298 & 2.611356 & 4.717371 & 3.502957 & 2.456002 & $\begin{array}{l}\text { mannose-specific } \\
\text { phosphotransferase system } \\
\text { component IID }\end{array}$ \\
\hline CEA_P0115 & CA_P0116 & 1.777221 & 2.342324 & 2.902238 & 3.126694 & 3.321994 & 5.378643 & xylanase \\
\hline
\end{tabular}

\begin{tabular}{|c|c|c|c|c|c|c|c|c|}
\hline \multicolumn{9}{|c|}{ Amino acid transport and metabolism } \\
\hline CEA_G0180 & CA_C0176 & 2.56498 & 2.063235 & 2.36635 & 2.08086 & 3.251555 & 3.705152 & $\begin{array}{l}\text { oligopeptide-binding protein, } \\
\text { periplasmic component }\end{array}$ \\
\hline CEA_G0327 & CA_C0316 & -4.09229 & 6.429377 & 7.957548 & 6.881528 & 4.185199 & 2.037144 & ornithine carbomoyltransferase \\
\hline CEA_G0390 & CA_C0380 & -4.23921 & 5.06975 & 5.365591 & 5.142555 & 3.394778 & 2.099342 & $\begin{array}{l}\text { periplasmic amino acid-binding } \\
\text { protein }\end{array}$ \\
\hline CEA_G0984 & CA_C0973 & -4.67305 & 6.390879 & 8.78089 & 7.141168 & 3.889621 & 2.522783 & argininosuccinate synthase \\
\hline CEA_G0985 & CA_C0974 & -4.03279 & 6.033303 & 8.738086 & 7.66813 & 4.662246 & 3.462605 & argininosuccinate lyase \\
\hline CEA_G2392 & CA_C2377 & -4.81354 & -4.50847 & -4.89131 & -5.25303 & -5.6598 & -6.94396 & $\begin{array}{l}\text { oligopeptide ABC-type transporter, } \\
\text { periplasmic binding component } \\
\text { (frameshift) }\end{array}$ \\
\hline CEA_G2403 & CA_C2388 & -3.653 & 6.58659 & 9.490741 & 7.214547 & 3.839977 & 1.277684 & acetylornithine aminotransferase \\
\hline CEA_G2405 & CA_C2390 & -4.029 & 7.044851 & 9.332151 & 8.593887 & 5.225523 & 1.729156 & $\begin{array}{l}\mathrm{N} \text {-acetyl-gamma-glutamyl- } \\
\text { phosphate reductase }\end{array}$ \\
\hline CEA_G2406 & CA_C2391 & -3.63924 & 6.659273 & 9.430206 & 8.041522 & 4.889782 & 1.658329 & $\begin{array}{l}\text { bifunctional ornithine } \\
\text { acetyltransferase/N-acetylglutamate } \\
\text { synthase protein }\end{array}$ \\
\hline CEA_G2531 & CA_C2517 & 2.601974 & 2.875402 & 3.244092 & 4.199853 & 5.407919 & 5.659197 & $\begin{array}{l}\text { extracellular neutral } \\
\text { metalloprotease, NPRE }\end{array}$ \\
\hline CEA_G3059 & CA_C3053 & -3.80847 & -4.46351 & -4.85998 & -5.20027 & -5.64176 & -4.16398 & $\begin{array}{l}\text { histidinol phosphatase related } \\
\text { enzyme }\end{array}$ \\
\hline CEA_G3625 & CA_C3618 & -2.33371 & 4.975742 & 4.579403 & 4.356899 & 3.79613 & 1.400104 & $\begin{array}{l}\text { ABC-type polar amino acid } \\
\text { transport system, ATPase } \\
\text { component }\end{array}$ \\
\hline
\end{tabular}


Table 4 List of differentially regulated genes in key functional groups (Continued)

\begin{tabular}{|c|c|c|c|c|c|c|c|c|}
\hline CEA_G3626 & CA_C3619 & -2.49499 & 4.94909 & 4.797836 & 4.831871 & 4.227636 & 1.349231 & $\begin{array}{l}\text { amino acid } A B C \text { transporter } \\
\text { permease }\end{array}$ \\
\hline CEA_G3627 & CA_C3620 & -2.79225 & 4.869307 & 2.77014 & 4.039679 & 3.923914 & 1.658129 & $\begin{array}{l}\text { amino acid } \mathrm{ABC} \text { transporter } \\
\text { periplasmic-binding protein }\end{array}$ \\
\hline CEA_G3629 & CA_C3622 & 3.744723 & 1.616914 & -1.60643 & -2.30924 & -3.70552 & -4.20925 & $\begin{array}{l}\text { benzoyl-CoA reductase/2- } \\
\text { hydroxyglutaryl-CoA dehydratase }\end{array}$ \\
\hline CEA_G3648 & CA_C3641 & 3.877563 & 5.273677 & 6.532841 & 7.05381 & 6.150331 & 2.645978 & $\begin{array}{l}\text { oligopeptide ABC transporter, } \\
\text { ATPase component }\end{array}$ \\
\hline CEA_G3649 & CA_C3642 & 3.862767 & 5.064748 & 6.213521 & 7.100308 & 6.123778 & 2.328286 & $\begin{array}{l}\text { oligopeptide ABC transporter, } \\
\text { ATPase component }\end{array}$ \\
\hline CEA_G3651 & CA_C3644 & 3.540737 & 4.731217 & 4.796332 & 6.751584 & 6.151055 & 3.301733 & $\begin{array}{l}\text { oligopeptide } \mathrm{ABC} \text { transporter, } \\
\text { permease component }\end{array}$ \\
\hline \multicolumn{9}{|c|}{ Lipid transport and metabolism } \\
\hline CEA_P0077 & CA_P0078 & -1.03663 & -2.39938 & -2.90422 & -5.61457 & -6.37659 & -6.669 & acetyl-CoA acetyltransferase \\
\hline CEA_G0500 & CA_C0489 & 2.843362 & 2.727643 & 3.104514 & 2.258672 & 2.789674 & 2.994569 & 4'-phosphopantetheinyl transferase \\
\hline CEA_G2024 & CA_C2009 & 3.02793 & 3.412819 & 2.753976 & 2.880761 & 2.465438 & 1.317947 & 3-hydroxyacyl-CoA dehydrogenase \\
\hline CEA_G2027 & CA_C2012 & 3.139119 & 3.519089 & 2.760385 & 2.466674 & 1.747722 & 1.295802 & enoyl-CoA hydratase \\
\hline CEA_G2023 & CA_C2008 & 3.21547 & 3.393795 & 2.65468 & 2.624962 & 1.849978 & 1.696553 & $\begin{array}{l}\text { 3-oxoacyl-(acyl-carrier-protein) } \\
\text { synthase }\end{array}$ \\
\hline CEA_G0825 & CA_C0814 & 3.447389 & 2.690101 & 3.341654 & 3.492821 & 2.738719 & 2.617536 & 3-oxoacyl- \\
\hline CEA_G3630 & CA_C3623 & 3.78405 & 1.698615 & -1.62094 & -2.13197 & -3.66189 & -4.47732 & $\begin{array}{l}\text { 2-hydroxyglutaryl-CoA dehydratase } \\
\text { activator }\end{array}$ \\
\hline \multicolumn{9}{|c|}{$\begin{array}{l}\text { Coenzyme transport and } \\
\text { metabolism }\end{array}$} \\
\hline CEA_G2539 & CA_C2526 & -5.80423 & -4.29934 & -2.18936 & -3.20732 & -2.04208 & -2.09088 & $\begin{array}{l}\text { 6-pyruvoyl-tetrahydropterin } \\
\text { synthase related protein }\end{array}$ \\
\hline CEA_G0110 & CA_C0109 & -1.93293 & -1.10289 & -4.51818 & -4.22606 & -3.40598 & -5.95312 & $\begin{array}{l}\text { sulfate adenylyltransferase } \\
\text { subunit } 2\end{array}$ \\
\hline CEA_G2240 & CA_C2226 & 1.175604 & 1.630568 & 1.933437 & 3.44313 & 4.132037 & 3.011011 & $\begin{array}{l}\text { branched-chain amino acid } \\
\text { aminotransferase }\end{array}$ \\
\hline CEA_G2817 & CA_C2809 & 1.909506 & 2.362089 & 1.59545 & 3.297164 & 2.183049 & 1.029092 & HD superfamily hydrolase \\
\hline CEA_G2037 & CA_C2022 & 2.45013 & 1.945668 & 2.521958 & 2.427533 & 2.187431 & 3.238565 & $\begin{array}{l}\text { molybdopterin biosynthesis protein } \\
\text { MoaB }\end{array}$ \\
\hline CEA_G3633 & CA_C3626 & 2.627562 & 1.339719 & -1.38437 & -2.32524 & -3.57634 & -5.06491 & GTP cyclohydrolase I \\
\hline CEA_G2036 & CA_C2021 & 2.849463 & 2.144804 & 2.666979 & 4.297463 & 3.319713 & 3.863173 & $\begin{array}{l}\text { molybdopterin biosynthesis protein } \\
\text { MoeA }\end{array}$ \\
\hline CEA_G2009 & CA_C1994 & 3.136184 & 3.75827 & 3.408469 & 2.84809 & 1.881193 & 1.268359 & $\begin{array}{l}\text { molybdopterin biosynthesis protein } \\
\text { MoaB }\end{array}$ \\
\hline CEA_G2035 & CA_C2020 & 3.146626 & 3.515592 & 5.182665 & 4.677354 & 4.692789 & 4.012931 & $\begin{array}{l}\text { molybdopterin biosynthesis protein } \\
\text { MoeA }\end{array}$ \\
\hline CEA_G3631 & CA_C3624 & 3.416604 & 1.490697 & -1.38827 & -2.23319 & -3.83641 & -6.15768 & $\begin{array}{l}\text { 6-pyruvoyl-tetrahydropterin } \\
\text { synthase }\end{array}$ \\
\hline \multicolumn{9}{|c|}{ Signal transduction } \\
\hline CEA_G0078 & CA_C0078 & -4.99228 & -8.71284 & -9.43594 & -9.21854 & -9.14927 & -7.97564 & $\begin{array}{l}\text { putative accessory gene regulator } \\
\text { protein }\end{array}$ \\
\hline CEA_G3328 & CA_C3325 & -1.00804 & -2.85267 & -4.3502 & -5.19446 & -4.39209 & -5.05262 & $\begin{array}{l}\text { periplasmic amino acid binding } \\
\text { protein }\end{array}$ \\
\hline CEA_G0921 & CA_C0909 & -2.84748 & -1.88833 & -1.93256 & -1.50557 & -2.64087 & -2.89144 & $\begin{array}{l}\text { methyl-accepting chemotaxis } \\
\text { protein }\end{array}$ \\
\hline CEA_G2085 & CA_C2071 & 2.455498 & 2.263411 & 2.413649 & 1.803983 & 2.20351 & 2.550339 & Spo0A protein \\
\hline CEA_G2422 & CA_C2407 & 3.784844 & 1.475039 & 1.927948 & 1.823945 & 2.526403 & 2.502499 & $\begin{array}{l}\text { CheY-like domain-containing } \\
\text { protein }\end{array}$ \\
\hline CEA_G0448 & CA_C0437 & 2.192653 & 1.378372 & 2.665966 & 1.827148 & 2.252286 & 2.342264 & $\begin{array}{l}\text { sensory transduction histidine } \\
\text { kinase }\end{array}$ \\
\hline CEA_G3025 & CA_C3019 & -2.65448 & 3.491201 & 3.449102 & 2.735229 & 1.336433 & 1.266833 & sensory transduction protein \\
\hline CEA_G0296 & CA_C0289 & 1.792323 & 1.978035 & 2.438903 & 2.751395 & 3.435751 & 3.052853 & response regulator \\
\hline
\end{tabular}


Table 4 List of differentially regulated genes in key functional groups (Continued)

\begin{tabular}{|c|c|c|c|c|c|c|c|c|}
\hline CEA_G2782 & CA_C2774 & 1.625932 & 1.895382 & 3.060796 & 2.846554 & 2.092881 & 1.726376 & $\begin{array}{l}\text { methyl-accepting chemotaxis } \\
\text { protein }\end{array}$ \\
\hline CEA_G0334 & CA_C0323 & 3.362504 & 2.662176 & 2.652177 & 3.222052 & 4.952742 & 2.037345 & $\begin{array}{l}\text { sensory transduction histidine } \\
\text { kinase }\end{array}$ \\
\hline CEA_G3627 & CA_C3620 & -2.79225 & 4.869307 & 2.77014 & 4.039679 & 3.923914 & 1.658129 & $\begin{array}{l}\text { amino acid } A B C \text { transporter } \\
\text { periplasmic-binding protein }\end{array}$ \\
\hline CEA_G0390 & CA_C0380 & -4.23921 & 5.06975 & 5.365591 & 5.142555 & 3.394778 & 2.099342 & $\begin{array}{l}\text { periplasmic amino acid-binding } \\
\text { protein }\end{array}$ \\
\hline \multicolumn{9}{|c|}{ Energy production and convertion } \\
\hline CEA_G1083 & CA_C1072 & 3.271648 & 3.230747 & 4.254617 & 2.59071 & 2.723209 & 3.766376 & Fe-S oxidoreductase \\
\hline CEA_G2012 & CA_C1997 & 3.052977 & 3.503142 & 3.004392 & 2.8712 & 2.075025 & 1.372718 & glycosyltransferase \\
\hline CEA_G2015 & CA_C2000 & 2.963078 & 3.638083 & 2.745804 & 2.983214 & 2.587284 & 2.204476 & $\begin{array}{l}\text { indolepyruvate oxidoreductase } \\
\text { subunit beta }\end{array}$ \\
\hline CEA_G2016 & CA_C2001 & 2.832561 & 3.688549 & 3.007107 & 3.355002 & 2.718563 & 2.206461 & $\begin{array}{l}\text { indolepyruvate ferredoxin } \\
\text { oxidoreductase, subunit }\end{array}$ \\
\hline CEA_G2022 & CA_C2007 & 3.179932 & 3.308867 & 2.812136 & 2.509044 & 1.656072 & 1.958591 & glycosyltransferase \\
\hline CEA_G2025 & CA_C2010 & 3.282342 & 3.533526 & 2.84142 & 3.003615 & 2.50221 & 2.005231 & Fe-S oxidoreductase \\
\hline CEA_G2555 & CA_C2542 & 8.22595 & 5.876659 & 5.423124 & 5.135223 & 4.224852 & 4.280766 & $\begin{array}{l}\text { FAD/FMN-containing } \\
\text { dehydrogenase }\end{array}$ \\
\hline CEA_G2556 & CA_C2543 & 8.451735 & 6.100494 & 5.401602 & 5.24343 & 4.426238 & 3.987954 & $\begin{array}{l}\text { electron-transferring flavoprotein } \\
\text { large subunit }\end{array}$ \\
\hline CEA_G2557 & CA_C2544 & 7.904188 & 6.040402 & 4.848558 & 4.578106 & 4.214698 & 3.969443 & $\begin{array}{l}\text { electron-transferring flavoprotein } \\
\text { small subunit }\end{array}$ \\
\hline CEA_G3411 & CA_C3408 & -2.71993 & -3.64684 & -4.53359 & -4.7967 & -4.89809 & -4.45863 & NADH oxidase \\
\hline \multicolumn{9}{|c|}{ Cell mobility } \\
\hline$\overline{C E A \_G 0921 ~}$ & CA_C0909 & -2.84748 & -1.88833 & -1.93256 & -1.50557 & -2.64087 & -2.89144 & $\begin{array}{l}\text { methyl-accepting chemotaxis } \\
\text { protein }\end{array}$ \\
\hline CEA_G3572 & CA_C3565 & 1.783589 & 1.966743 & 1.626123 & 1.303128 & 1.522492 & 1.56009 & $\begin{array}{l}\text { cell adhesion domain-containing } \\
\text { protein }\end{array}$ \\
\hline CEA_G3091 & CA_C3085 & 1.669031 & 1.879947 & 1.641572 & 3.329325 & 2.811493 & 2.558158 & $\begin{array}{l}\text { TPR repeat-containing cell } \\
\text { adhesion protein }\end{array}$ \\
\hline CEA_G3092 & CA_C3086 & 1.689695 & 1.7646 & 1.823344 & 3.167841 & 2.629106 & 2.423856 & $\begin{array}{l}\text { cell adhesion domain-containing } \\
\text { protein }\end{array}$ \\
\hline CEA_G2782 & CA_C2774 & 1.625932 & 1.895382 & 3.060796 & 2.846554 & 2.092881 & 1.726376 & $\begin{array}{l}\text { methyl-accepting chemotaxis } \\
\text { protein }\end{array}$ \\
\hline CEA_P0159 & CA_P0160 & 2.878477 & 3.739495 & 3.515178 & 3.50976 & 3.19802 & 3.547315 & $\begin{array}{l}\text { cell-adhesion domain-containing } \\
\text { protein }\end{array}$ \\
\hline
\end{tabular}

variation in $c c p A$ promoter region still needs further investigation.

\section{$\operatorname{agrC}$ and sigma factor variations may involve in spore formation in EA 2018}

Comparative genomic analysis identified several genes which may be accounted for difference in terms of spore formation (Table 2). Among these muted genes, CEA_G2066 (CAC2052 in ATCC 824) encodes a putative sigma factor. It has been known that the transcription of this gene was closely related to spore-formation in ATCC 824 [40]. CEA_G2066 has a single nucleotide (A) insertion site in $687-688^{\text {th }}$ bases, which altered the C-terminal protein sequence. Transcriptomic analysis showed that the transcription level of CEA_G2066 and other 4 putative sporulation related sigma factors [40] was lower in EA 2018 at 21 h, 24 h and 30 h (Figure 6), which might contribute to non-sporulation property in EA 2018.

Quarum sensing is related to some important characteristics of bacteria, such as sporulation, virulence, and biofilm formation [41]. In C. perfringens, the virulence gene was regulated by agr system, and agrBD knockout mutant did not express theta-toxin gene, and transcription of the alpha- and kappa-toxin genes was also significantly decreased in the mutant strain [42]. A twocomponent system gene, CEA_G0080 (CAC0080 in ATCC 824), encoding a histidine kinase-like ATPase (AgrC), has a single nucleotide (A) insertion site in $1159-1160^{\text {th }}$ bases when compared with $\operatorname{agrC}$ gene in ATCC 824, which may truncate the protein encoding sequence. In addition, the expression level of $\operatorname{agr} B$ 
Table 5 DNA and transcriptional variations of putative promoter variations between EA 2018 and ATCC 824

\begin{tabular}{|c|c|c|c|c|c|c|c|c|c|c|}
\hline $\begin{array}{l}\text { Gene } \\
\text { locus in } \\
\text { EA } 2018\end{array}$ & $\begin{array}{l}\text { Gene } \\
\text { locus in } \\
\text { ATCC } \\
824\end{array}$ & $\begin{array}{r}\text { Gene } \\
\text { varition } \\
\text { site in } \\
2018\end{array}$ & $\begin{array}{r}\text { Gene } \\
\text { varition } \\
\text { site in } \\
824\end{array}$ & $\begin{array}{r}9 \mathrm{~h} \\
\left(\log _{2} \text { Ratio }\right. \\
2018 / 824)\end{array}$ & $\begin{array}{r}13 \mathrm{~h} \\
\left(\log _{2} \text { Ratio }\right. \\
2018 / 824)\end{array}$ & $\begin{array}{r}17 \mathrm{~h} \\
\left(\log _{2} \text { Ratio }\right. \\
2018 / 824)\end{array}$ & $\begin{array}{r}21 \mathrm{~h} \\
\left(\log _{2} \text { Ratio }\right. \\
2018 / 824)\end{array}$ & $\begin{array}{r}24 \mathrm{~h} \\
\left(\log _{2} \text { Ratio }\right. \\
2018 / 824)\end{array}$ & $\begin{array}{r}30 \mathrm{~h} \\
\left(\log _{2} \text { Ratio }\right. \\
2018 / 824)\end{array}$ & Product Name \\
\hline CEA_G0334 & CA_C0323 & $-96(A)$ & $\begin{array}{r}-(97-96) \\
(-)\end{array}$ & 3.362504 & 2.662176 & 2.652177 & 3.222052 & 4.952742 & 2.037345 & $\begin{array}{l}\text { Sensory } \\
\text { transduction } \\
\text { histidine kinase }\end{array}$ \\
\hline CEA_G0390 & CA_C0380 & $\begin{array}{r}-135,-131 \\
(A, A)\end{array}$ & $\begin{array}{r}-135,-131 \\
(T, T)\end{array}$ & -4.23921 & 5.06975 & 5.365591 & 5.142555 & 3.394778 & 2.099342 & $\begin{array}{l}\text { Periplasmic amino } \\
\text { acid-binding } \\
\text { protein }\end{array}$ \\
\hline CEA_G2504 & CA_C2490 & $\begin{array}{r}-(13-12),- \\
53(-, T)\end{array}$ & $\begin{array}{r}-12,-(54- \\
53)(C,-)\end{array}$ & -2.39555 & -3.35613 & -3.80832 & -2.2032 & -2.7562 & -1.10185 & $\begin{array}{l}\text { Xre family DNA- } \\
\text { binding domain } \\
\text { and TPR repeats } \\
\text { containing protein }\end{array}$ \\
\hline CEA_G3701 & CA_C3694 & $-43(T)$ & $-43(C)$ & 4.045439 & 3.430925 & 3.859781 & 3.69948 & 4.131629 & 3.75554 & $\begin{array}{l}\text { TPR-repeat- } \\
\text { containing protein }\end{array}$ \\
\hline CEA_P0034 & CA_P0035 & $-84(T)$ & $-84(C)$ & 3.331902 & 5.740285 & 6.007483 & 8.056546 & 6.576379 & 7.664691 & $\begin{array}{l}\text { Aldehyde-alcohol } \\
\text { dehydrogenase, } \\
\text { AdhEll }\end{array}$ \\
\hline
\end{tabular}

(CEA_G0078) was constantly lower in EA 2018 (Figure 3). Early studies suggested that deletion of any agr system genes could result in no spore formation in ATCC 824 [43]. Therefore, mutation in $\operatorname{agrC}$ gene and lower expression of $\operatorname{agr} B$ gene in EA 2018 might be responsible for to the non-sporulation property in EA 2018.

\section{Conclusion}

A hyper-butanol, non spore-forming C. acetobutylicum EA 2018 strain we isolated previously can produce 10\% more butanol than the type strain C. acetobutylicum ATCC 824 [23]. To seek molecular basis of these characteristics in EA 2018 strain, we completed the genome sequencing of this strain using 454 GS FLX pyrosequceing and performed a detailed genomic comparison with a $C$. acetobutylicum type strain ATCC 824. Although EA 2018 was found more than $99.8 \%$ identical to ATCC 824, 72 indels (i.e. insertions and deletions) and 451 SNVs were identified, some of which may be related to the enhanced butanol production in EA 2018. In addition, we performed a comparative transcriptomic analysis of $C$. acetobutylicum EA 2018 and ATCC 824 using oligonucleotide microarrays. The results showed that increased expression of several key genes related to solvent formation, and decreased expression of the acid formation related genes may be related to the enhanced butanol production in EA 2018. Furthermore, the results also showed that the variation in
CEA_G2622 (CAC2613 in ATCC 824), a putative transcriptional regulator involved in xylose utilization, may be able to accelerate utilization of substarte xylose. The comparisons of hyper-butanol EA 2018 and type strain ATCC 824 at both genomic and transcriptomic levels not only improved our understanding of the hyper butanol-producing, xylose utilization as well as non-spore formation properties in EA 2018 strain, but also provided some useful clues for the future genetic modification of C. acetobutylicum to produce solvents, especially butanol more effectively.

\section{Methods}

\section{Bacteria strain and genome sequencing}

C. acetobutylicum EA 2018 (CCTCC M 94061) used for this study [22] is deposited in China Center for Type Culture Collection (http://www.cctcc.org/). C. acetobutylicum ATCC 824 was the wild type strain we purchased from American Type Culture Collection (ATCC) [23]. The C. acetobutylicum EA 2018 was grown anaerobically (Thermo Electron Crop., San Jose, USA). Colonies picked from Clostridia growth medium (CGM) plate were inoculated into $5 \mathrm{ml}$ liquid CGM and cultured at $37^{\circ} \mathrm{C}$ overnight [44], and then the cells were transferred into $100 \mathrm{ml} \mathrm{CGM} \mathrm{and}$ incubated at $37^{\circ} \mathrm{C}$ for $16-20 \mathrm{~h}$ until they reach lateexponential phase. Cells collected were used for

Table 6 Hydrogen production of C. acetobutylicum EA 2018 and C. acetobutylicum ATCC 824 in $6 \%$ glucose contained P2 medium

\begin{tabular}{lccc}
\hline & $\begin{array}{c}\text { Fermentation } \\
\text { Time }(\mathbf{h})\end{array}$ & $\begin{array}{c}\text { Glucose } \\
\text { consumed (mM) }\end{array}$ & $\begin{array}{c}\text { Hydrogen } \\
\text { production }(\mathbf{m M})\end{array}$ \\
\hline EA 2018 & 72 & $260.6 \pm 3.7$ & $244.1 \pm 1.3$ \\
ATCC 824 & 72 & $239.4 \pm 5.0$ & $315.4 \pm 0.5$ \\
\hline
\end{tabular}




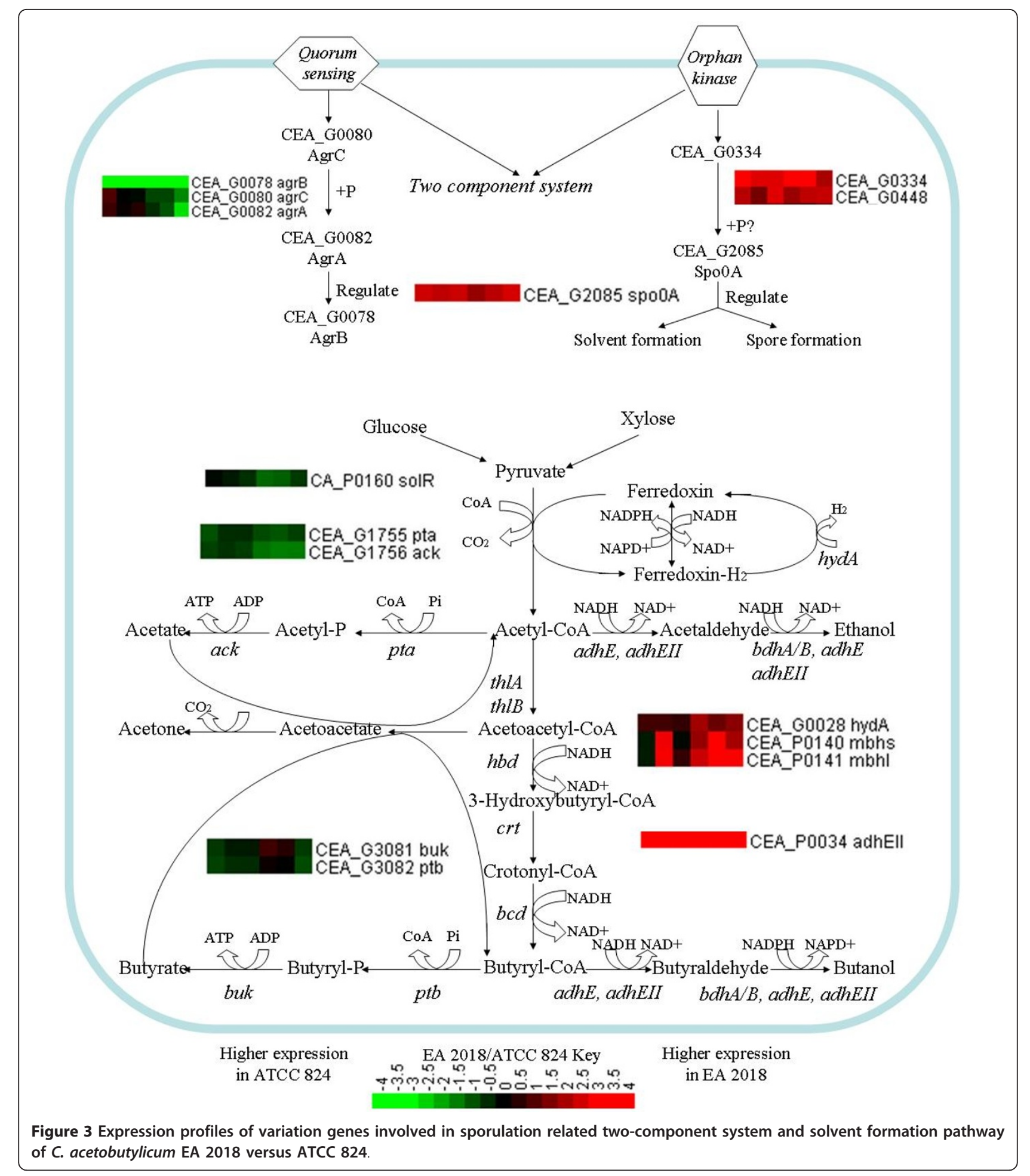

chromosomal DNA isolation as described previously [45]. Roche 454 GS FLX pyrosequencing was used to sequence the DNA. A total of 60.3 Megabases was generated, with an average read length of $200 \mathrm{bp}$. The GS FLX reads were assembled into a total of 198 contigs using a GS de novo assembler, among them, 157 contigs are larger than $500 \mathrm{bp}$. The gaps were closed by PCR procedure using the ATCC 824 genome sequence as reference. The large PCR products were sequenced via primer walking. The whole 


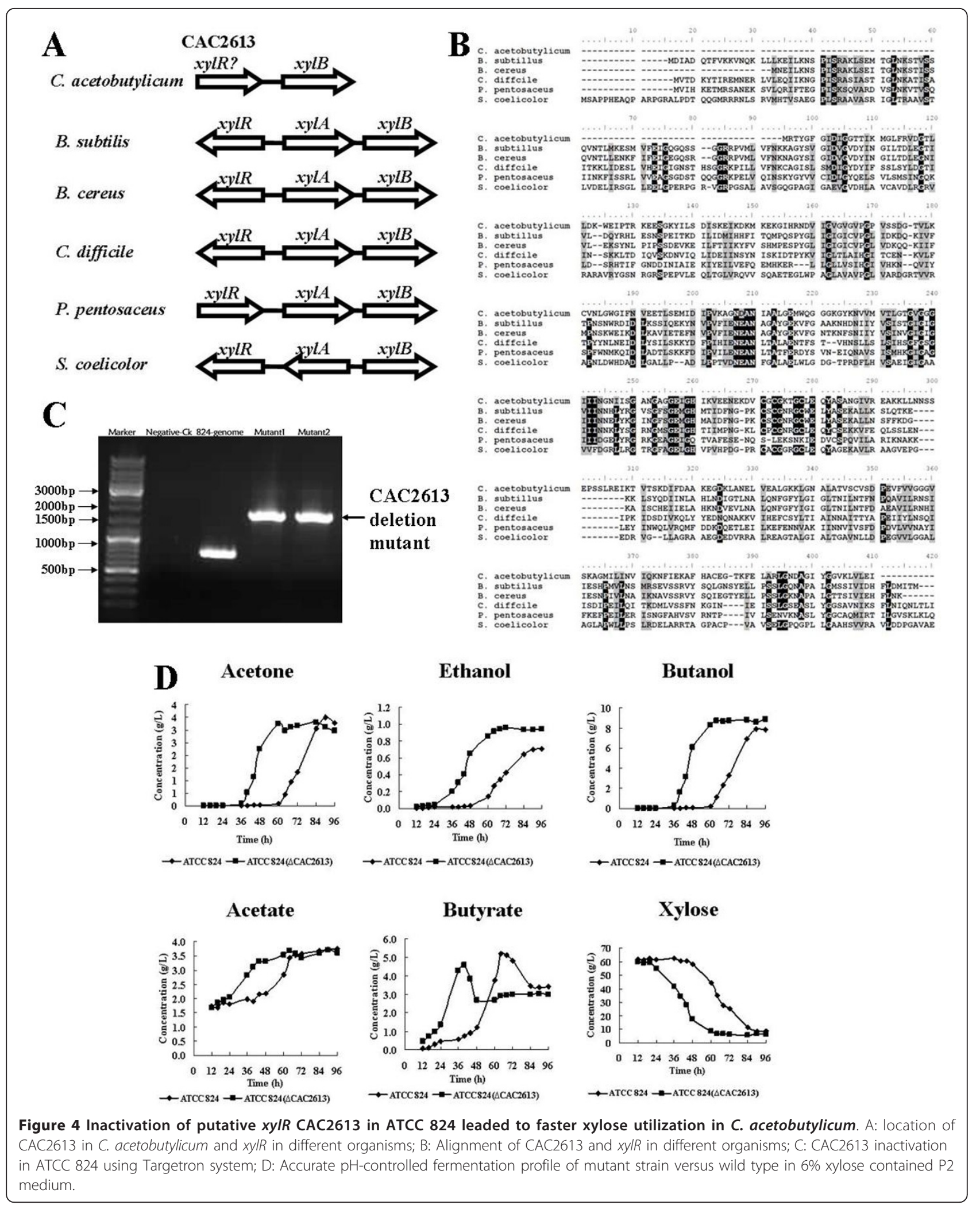




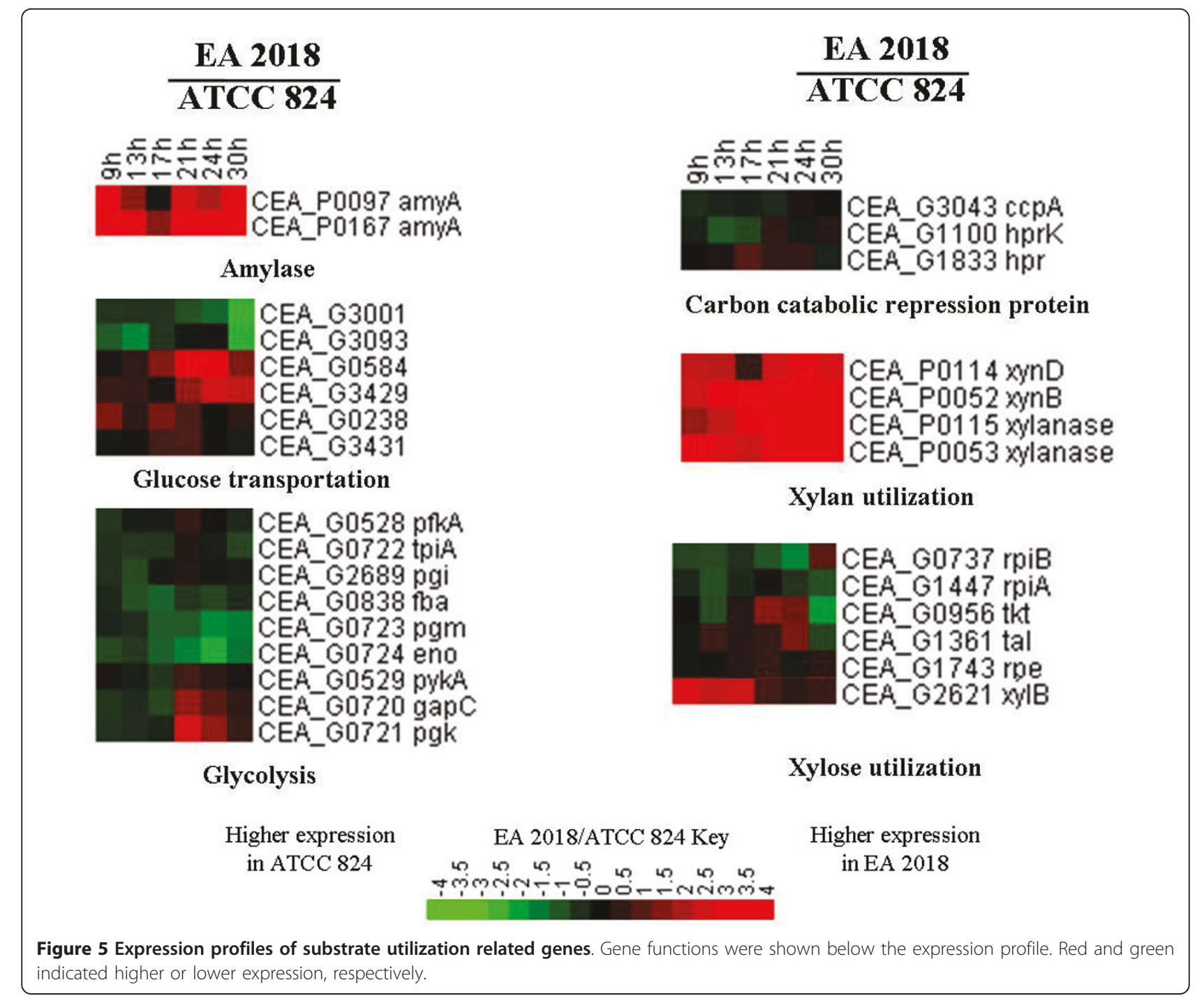

sequence was assembled by using the software phredPhrap (http://www.phrap.org) and was visualized by Consed [46]. The low-quality sequences were verified by PCR resequencing using ABI 3730 (Applied Biosystem Inc.). The sequence accuracy of the final genome was 99.9919\%. All the variation between EA 2018 and ATCC 824 were verified by PCR resequencing using ABI 3730.

\section{Genome annotation and bioinformatic analysis}

CDSs were identified by combining the results of ZCURVE 1.0 [47] and Glimmer 3.2 (http://www.cbcb. umd.edu/software/glimmer). Transfer RNA genes were predicted by tRNAscan-SE [48]. Functional annotation of CDSs was performed through comparison with NCBI non-redundant protein database using BLASTP, followed by manual curation. Comparative genomic analysis was performed by using the Artemis Comparison
Tool (ACT; http://www.sanger.ac.uk/resources/software/ act/). The atlas of the genome is drawn by using GenomeViz1.1 [49].

\section{Nucleotide sequence accession number}

The annotated genome sequence has been deposited into GenBank under accession no. CP002118 (Chromosome) and no. CP002119 (Plasmid).

\section{Oligonucleotide microarray experiments}

Cells for RNA isolation were grown on P2 medium and collected at $9 \mathrm{~h}, 13 \mathrm{~h}, 17 \mathrm{~h}, 21 \mathrm{~h}, 24 \mathrm{~h}$ and $30 \mathrm{~h}$ by centrifugation at $4^{\circ} \mathrm{C}$ and $4500 \times \mathrm{g}$ for $10 \mathrm{~min}$. Total RNA was extracted and purified by using Trizol (Invitrogen, Carlsbad, CA, USA) and RNeasy cleanup kit (Qiagen, Inc., Valencia, CA, USA) according to the manufacturer's protocol. The total RNA yield was quantified by spectrophotometric analysis (NanoDrop 


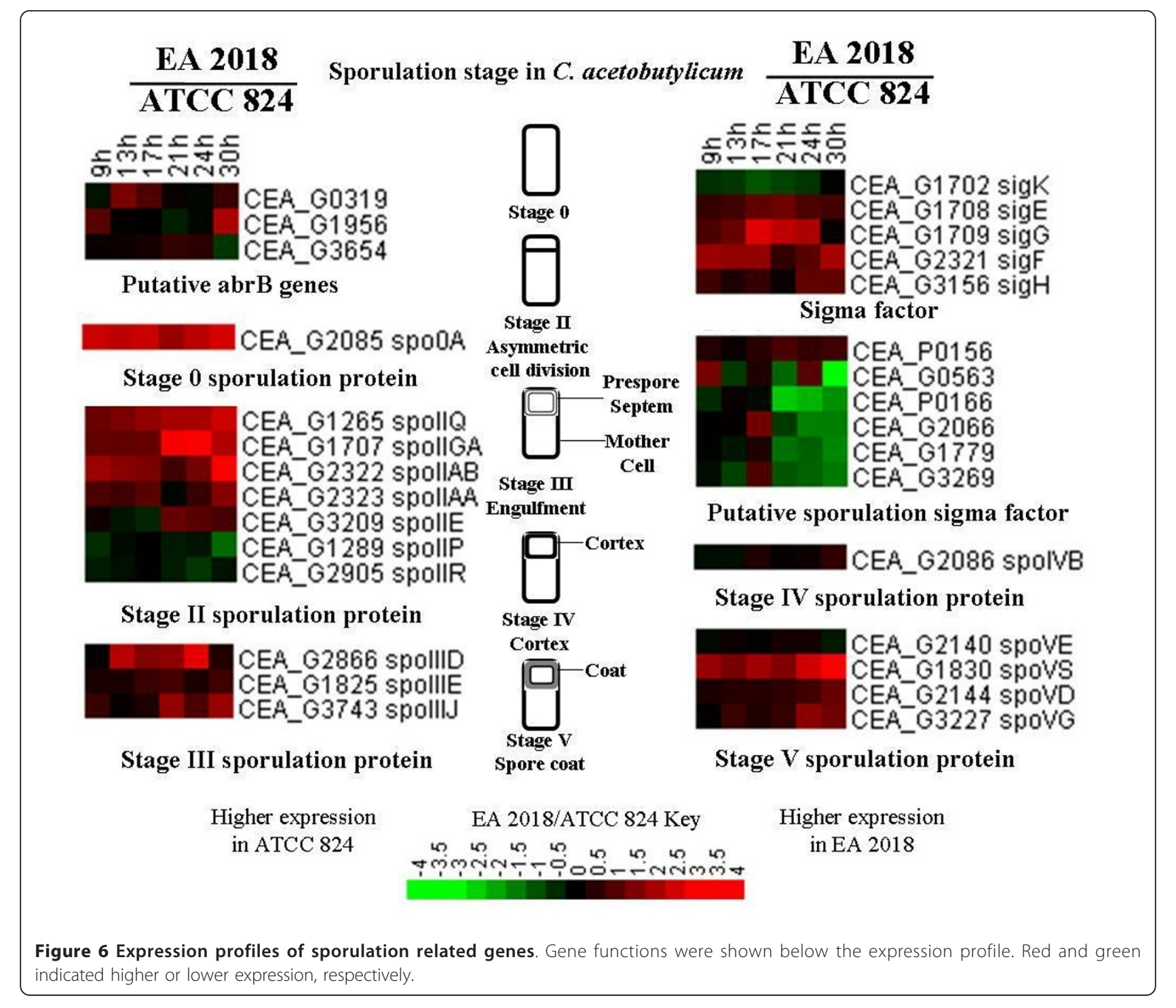

Technology, Cambridge, UK) and the quality was verified by gel electrophoresis. Agilent oligonucleotide microarrays technology was used for monochromic analysis, in which probes (size: $60 \mathrm{bp}$; three replicates for each ORF) from the two groups were labeled by incorporation of cyanine 3 (Cy3) (Agilent Technologies, Palo Alto, CA, USA). The experiment procedures and data normalization were performed using the methods described previously [50]. Average linkage hierarchical clustering was performed using Cluster 3.0, and gene clusters were visualized in Treeview [51].

Oligonucleotide microarray accession number The Oligonucleotide microarray data has been deposited into GEO under accession no. GSE23071.
Gene disruption

Gene disruption in C. acetobutylicum ATCC 824 was performed as described previously [11]. The disruption procedures were shown in Additional file 9. The selected site for CAC2613 disruption was 532/533a, where the group II intron will insert into gene CAC2613 coding region between amino acid 532 and 533 sites in the antisense direction. The primers (CAC2613-532-533-IBS, CAC2613-532-533-EBS1d and CAC2613-532-533-EBS2), for retargeting the RNA portion of the intron for $C$. acetobutylicum CAC2613 gene disruption, are listed in Additional file 10. The $350 \mathrm{bp}$ targetron fragment was obtained by PCR based on the plasmid pACD4K-C and protocol provided by the TargeTron ${ }^{\mathrm{TM}}$ Gene Knockout System Kit (SigmaAldrich, St Louis, MO, USA). The 350 bp PCR fragment 
was digested with $X h o I$ and $B s r \mathrm{GI}$, and then inserted into pSY6 [11] digested with the same restriction enzymes, to generate the plasmid pSY6-2613. The plasmid pSY6-2613 was methylated in E. coli ER2275 (pANS1) first [52], and then electroporated into C. acetobutylicum ATCC 824. Cells were plated on CGM agar containing $50 \mu \mathrm{g} / \mathrm{mL}$ erythromycin and incubated at $37^{\circ}$ $\mathrm{C}$ for about 2-3 days. The positive transformants containing the inserted intron were identified by colony PCR, using primers CAC2613-ID-fw and CAC2613-IDrev (Additional file 10).

\section{Fermentation conditions}

Solvent production and sugar utilization of C. acetobutylicum ATCC 824 and C. acetobutylicum EA 2018 were determined when the cultures were grown on P2 medium [53]. 6\% Glucose or xylose contained P2 solution I $(840 \mathrm{ml})$ and $\mathrm{KH}_{2} \mathrm{PO}_{4}(0.5 \mathrm{~g} / \mathrm{L}), \mathrm{K}_{2} \mathrm{HPO}_{4}(0.5 \mathrm{~g} /$ L), $\mathrm{CH}_{3} \mathrm{COONH}_{4}(2.2 \mathrm{~g} / \mathrm{L})$ contained P2 solution II $(100 \mathrm{ml})$ were boiled for $20 \mathrm{~min}$, then cooled by flushing $\mathrm{O}_{2}$-free $\mathrm{N}_{2}$ gas, and autoclaved at $121^{\circ} \mathrm{C}$ for 15 min separately. After autoclaving, $100 \mathrm{ml} \mathrm{P} 2$ solution II, $10 \mathrm{ml}$ filter-sterilized P2 medium stock solution III $\left(\mathrm{MgSO}_{4} \cdot 7 \mathrm{H}_{2} \mathrm{O}, 20 \mathrm{~g} / \mathrm{L} ; \mathrm{MnSO}_{4} \cdot \mathrm{H}_{2} \mathrm{O}, 1 \mathrm{~g} / \mathrm{L} ; \mathrm{FeS}-\right.$ $\mathrm{O}_{4} \cdot 7 \mathrm{H}_{2} \mathrm{O}, 1 \mathrm{~g} / \mathrm{L} ; \mathrm{NaCl}, 1 \mathrm{~g} / \mathrm{L}$ ) and $1 \mathrm{ml}$ solution IV (Para-amino-benzoicacid, $0.1 \mathrm{~g} / \mathrm{L}$; thiamin, $0.1 \mathrm{~g} / \mathrm{L}$; biotin, $0.001 \mathrm{~g} / \mathrm{L}$ ) were added into P2 solution $\mathrm{I}$. The stock solutions were filter sterilized through a $0.2 \mu \mathrm{m}$ pore-size filter. An inoculum of 5\% from a CGM grown culture was typically used. Batch fermentation was carried out in $250 \mathrm{ml}$ sealed bottle with $100 \mathrm{ml}$ medium. $1 \mathrm{ml}$ samples were taken every $12 \mathrm{~h}$ and analyzed for solvent and sugar. Accurate $\mathrm{pH}$-controlled fermentations were carried out in BioFlo 110 bioreactors with $1.5 \mathrm{~L}$ working volume (New Brunswick Scientific, Edison, NJ). The $\mathrm{pH}$ control was achieved by using $9 \%(w / v)$ aqueous ammonia. Anaerobic conditions of fermentors were maintained through aeration of filtered nitrogen.

\section{Analytical methods}

The surface morphology of C. acetobutylicum EA 2018 was studied using a JSM-6360 scanning electron microscope (JEOL Co. Ltd. Japan). Spore formation analysis was performed by growing the cells in P2 medium. After $48 \mathrm{~h}$ fermentation, cells were collected by centrifuging at $10,000 \times \mathrm{g}$ for $5 \mathrm{~min}$, and stained with crystal violet for imaging analysis using a UCTR30-2 microscope (Olympus Optical Co. Ltd. Japan). Butanol, acetone, ethanol, acetic acid and butyric acid were determined using a gas chromatograph (7890A, Agilent, Wilmington, DE, USA) equipped with a capillary column (Alltech ECTM WAX) and a flame ionization detector. The analysis was carried out under the following conditions: oven temperature, programmed from 80 to $140^{\circ} \mathrm{C}$ at a rate of $25^{\circ} \mathrm{C} / \mathrm{min}$; injector temperature, $200^{\circ} \mathrm{C}$; detector temperature, $200^{\circ} \mathrm{C}$; nitrogen (carrier gas) flow rate, $13 \mathrm{ml} / \mathrm{min}$; hydrogen flow rate, $20 \mathrm{ml} / \mathrm{min}$; air flow rate, $140 \mathrm{ml} / \mathrm{min}$. Total solvent was defined as the sum of ABE. Isobutylalcohol and isobutyric acid were used as the internal standards for ABE and acid determination, respectively. Glucose and xylose were determined using a HPLC system (Model 1200, Agilent) equipped with a sugar-pak I column (Waters) and a refractive index detector. The analysis was carried out with water as mobile phase at a rate of $0.6 \mathrm{ml} / \mathrm{min}$, and the column temperature was set up at $70^{\circ} \mathrm{C}$. The composition of the gas produced (mainly $\mathrm{H}_{2}$ and $\mathrm{CO}_{2}$ ) was measured using the method described previously [54].

\section{Additional material}

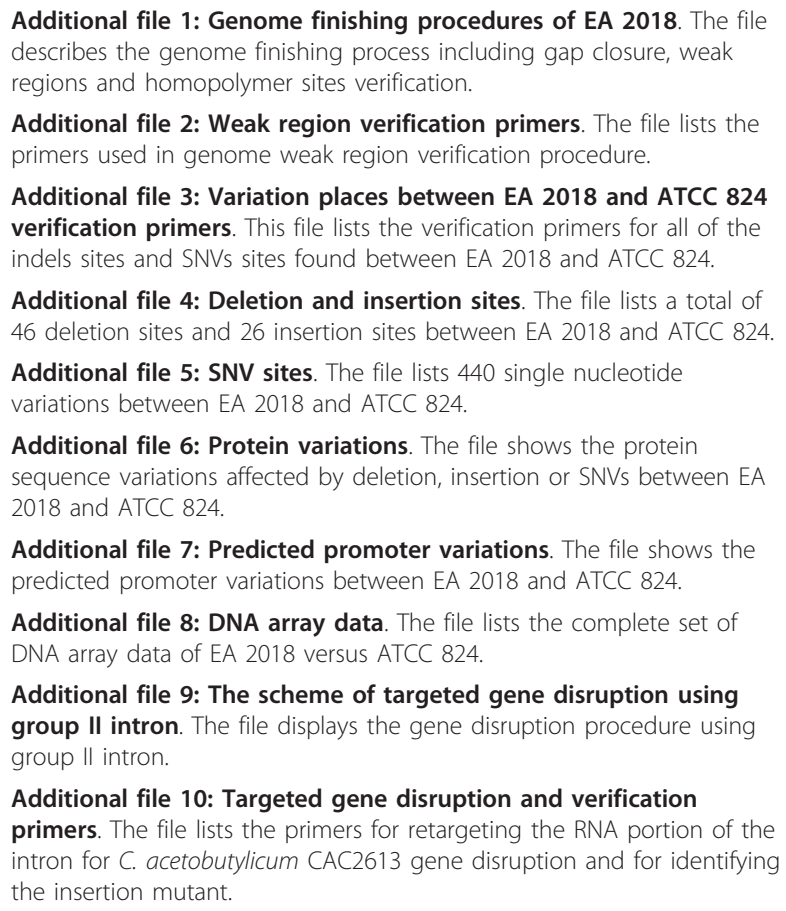

Additional file 7: Predicted promoter variations. The file shows the predicted promoter variations between EA 2018 and ATCC 824.

Additional file 8: DNA array data. The file lists the complete set of DNA array data of EA 2018 versus ATCC 824.

Additional file 9: The scheme of targeted gene disruption using group II intron. The file displays the gene disruption procedure using group II intron.

Additional file 10: Targeted gene disruption and verification primers. The file lists the primers for retargeting the RNA portion of the intron for C. acetobutylicum CAC2613 gene disruption and for identifying the insertion mutant.

\section{Abbreviations}

ABE: Acetone-Butanol-Ethanol; ATCC: American Type Culture Collection; CCTCC: China Center for Type Culture Collection; ORF: Open Reading Frames; NTG: N-methyl-N-nitro-N-nitrosoguanidine; SNVs: Single Nucleotide Variations; RBS: Ribosome Binding Site; CcpA: Catabolite Control Protein A; CGM: Clostridia Growth Medium.

\section{Acknowledgements}

This work was supported by National Basic Research Program of China (2007CB707803, 2011CBA00806), Knowledge Innovation Program of the Chinese Academy of Sciences (KSCX2-EW-G-1, KSCX2-EW-J-12), National Natural Science Foundation of China (31070075) and Key Program of 
Science and Technology Commission of Shanghai Municipality (08DZ1207100)

We thank Prof. Peter Duerre for providing the manipulation methods on Clostridium acetobutylicum. We thank Jun Chen, Huiqi He, Lijun Shao, Cong Ren, Yongqiang Zhu, Qiuping Hu, Yiwei Yang and Qing Tang for their kindly help on this project.

During the review process we realized there is a concern from one of the reviewers regarding the origin of EA 2018 used in this research due to its high genome sequence similarity with ATCC 824. Although all the historical records we know about indicated that this is an independently isolated strain [23], at this moment we would like to keep the discussion regarding its origin ongoing until further evidences emerge.

\section{Author details}

${ }^{1}$ Key Laboratory of Synthetic Biology, Institute of Plant Physiology and Ecology, Shanghai Institutes for Biological Sciences, Chinese Academy of Sciences, Shanghai 200032, China. ${ }^{2}$ Research Center of Industrial Biotechnology, Shanghai Institutes for Biological Sciences, Chinese Academy of Sciences, Shanghai 200032, China. ${ }^{3}$ Shanghai-MOST Key Laboratory of Health and Disease Genomics, Chinese National Human Genome Center at Shanghai, Shanghai, 200032, China. ${ }^{4}$ Center for Ecogenomics, Biodesign Institute, Arizona State University, Tempe, Arizona 85287-6501, USA.

\section{Authors' contributions}

SYH, YLY, GPZ, SY, WHJ conceived of the study. SYH performed the genome sequencing, microarray samples preparation and gene disruption. SYH and YG performed the strain fermentation and analysis. JBZ performed the spore formation analysis. SYH, HJZ and SYW performed the genome annotation and analysis work. SYH and WWZ drafted the manuscript. All authors contributed to and approved the final manuscript.

Received: 5 August 2010 Accepted: 2 February 2011

Published: 2 February 2011

\section{References}

1. Durre P: Biobutanol: an attractive biofuel. J Biotechno/ 2007, 2:1525-1534.

2. Durre P: New insights and novel developments in clostridial acetone/ butanol/isopropanol fermentation. Appl Microbiol Biotechnol 1998, 49:639-648.

3. Demain AL, Newcomb M, Wu JHD: Cellulase, Clostridia, and Ethanol. Microbiol Mol Biol Rev 2005, 69:124-154.

4. Lee SY, Park JH, Jang SH, Nielsen LK, Kim J, Jung KS: Fermentative butanol production by Clostridia. Biotechnol Bioeng 2008, 101:209-228.

5. Nair RV, Green EM, Watson DE, Bennett GN, Papoutsakis ET: Regulation of the sol locus genes for butanol and acetone formation in Clostridium acetobutylicum ATCC 824 by a putative transcriptional repressor. $J$ Bacteriol 1999, 181:319-330

6. Gorwa MF, Croux C, Soucaille P: Molecular characterization and transcriptional analysis of the putative hydrogenase gene of Clostridium acetobutylicum ATCC 824. J Bacteriol 1996, 178:2668-2675.

7. Boynton ZL, Bennet GN, Rudolph FB: Cloning, sequencing, and expression of clustered genes encoding beta-hydroxybutyryl-coenzyme A (CoA) dehydrogenase, crotonase, and butyryl-CoA dehydrogenase from Clostridium acetobutylicum ATCC 824. J Bacteriol 1996, 178:3015-3024

8. Hueck CJ, Kraus A, Schmiedel D, Hillen W: Cloning, expression and functional analyses of the catabolite control protein CcpA from Bacillus megaterium. Mol Microbiol 1995, 16:855-864.

9. Sillers R, Al-Hinai MA, Papoutsakis ET: Aldehyde-alcohol dehydrogenase and/ or thiolase overexpression coupled with CoA transferase downregulation lead to higher alcohol titers and selectivity in Clostridium acetobutylicum fermentations. Biotechnol Bioeng 2009, 102:38-49.

10. Papoutsakis ET: Engineering solventogenic clostridia. Curr Opin Biotechnol 2008, 19:420-429.

11. Shao L, Hu S, Yang Y, Gu Y, Chen J, Yang Y, Jiang W, Yang S: Targeted gene disruption by use of a group II intron (targetron) vector in Clostridium acetobutylicum. Cell Res 2007, 17:963-965.

12. Nolling J, Breton G, Omelchenko MV, Makarova KS, Zeng Q, Gibson R, Lee HM, Dubois J, Qiu D, Hitti J: Genome sequence and comparative analysis of the solvent-producing bacterium Clostridium acetobutylicum. J Bacteriol 2001, 183:4823-4838.
13. Mao SM, Luo YAM, Zhang TR, Li JS, Bao GAH, Zhu Y, Chen ZG, Zhang YP, Li Y, Ma YH: Proteome Reference Map and Comparative Proteomic Analysis between a Wild Type Clostridium acetobutylicum DSM 1731 and its Mutant with Enhanced Butanol Tolerance and Butanol Yield. $J$ Proteome Res 2010, 9:3046-3061.

14. Shi Z, Blaschek HP: Transcriptional analysis of Clostridium beijerinckii NCIMB 8052 and the hyper-butanol-producing mutant BA101 during the shift from acidogenesis to solventogenesis. Appl Environ Microbiol 2008, 74:7709-7714.

15. Paredes CJ, Senger RS, Spath WS, Borden JR, Sillers R, Papoutsakis ET: A general framework for designing and validating oligomer-based DNA microarrays and its a application to Clostridium acetobutylicum. Appl Environ Microbiol 2007, 73:4631-4638.

16. Sullivan L, Bennett GN: Proteome analysis and comparison of Clostridium acetobutylicum ATCC 824 and Spo0A strain variants. J Ind Microbiol Biotechnol 2006, 33:298-308.

17. Lee J, Yun H, Feist AM, Palsson BO, Lee SY: Genome-scale reconstruction and in silico analysis of the Clostridium acetobutylicum ATCC 824 metabolic network. Appl Microbiol Biotechnol 2008, 80:849-862.

18. Ryan S, Senger ETP: Genome-Scale Model for Clostridium acetobutylicum. Part 2: Development of Specific Proton Flux States and NumericallyDetermined Sub-Systems. Biotechnol Bioeng 2008, 101:1053-1071.

19. Ryan S, Senger ETP: Genome-scale model for Clostridium acetobutylicum. Part 1: Metabolic network resolution and analysis. Biotechnol Bioeng 2008, 101:1036-1052

20. Durre P, Fischer RJ, Kuhn A, Lorenz K, Schreiber W, Sturzenhofecker B, Ullmann S, Winzer K, Sauer U: Solventogenic enzymes of Clostridium acetobutylicum: catalytic properties, genetic organization, and transcriptional regulation. FEMS Microbiol Rev 1995, 17:251-262.

21. Annous BA, Blaschek HP: Isolation and characterization of Clostridium acetobutylicum mutants with enhanced amylolytic activity. Appl Environ Microbiol 1991, 57:2544-2548.

22. Zhang $Y$, Chen J, Yang Y, Jiao R: Breeding high-ration butanol strains of Clostridium acetobutylicum and application to industrial production. Industrial Microbiology (in Chinese) 1996, 26:1-6.

23. Chiao JS, Sun ZH: History of the Acetone-Butanol-Ethanol Fermentation Industry in China: Development of Continuous Production Technology. J Mol Microbiol Biotechnol 2007, 13:12-14.

24. Fischer RJ, Helms J, Durre P: Cloning, sequencing, and molecular analysis of the sol operon of Clostridium acetobutylicum, a chromosomal locus involved in solventogenesis. J Bacteriol 1993, 175:6959-6969.

25. Fontaine L, Meynial-Salles I, Girbal L, Yang XH, Croux C, Soucaille P: Molecular characterization and transcriptional analysis of adhE2, the gene encoding the NADH-dependent aldehyde/alcohol dehydrogenase responsible for butanol production in alcohologenic cultures of Clostridium acetobutylicum ATCC 824. J Bacteriol 2002, 184:821-830.

26. Harris LM, Welker NE, Papoutsakis ET: Northern, morphological, and fermentation analysis of spo0A inactivation and overexpression in Clostridium acetobutylicum ATCC 824. J Bacteriol 2002, 184:3586-3597.

27. Paredes CJ, Alsaker KV, Papoutsakis ET: A comparative genomic view of clostridial sporulation and physiology. Nat Rev Microbiol 2005, 3:969-978.

28. Rao G, Mutharasan R: Altered Electron Flow in Continuous Cultures of Clostridium acetobutylicum Induced by Viologen Dyes. Appl Environ Microbiol 1987, 53:1232-1235.

29. Nakayama Si, Kosaka T, Hirakawa H, Matsuura K, Yoshino S, Furukawa K: Metabolic engineering for solvent productivity by downregulation of the hydrogenase gene cluster hupCBA in Clostridium saccharoperbutylacetonicum strain N1-4. Appl Microbiol Biotechnol 2008 78:483-493.

30. Haggstrom L: Acetone-butanol fermentation and its variants. Biotechnol Adv 1985, 3:13-28.

31. Grupe H, Gottschalk G: Physiological Events in Clostridium acetobutylicum during the Shift from Acidogenesis to Solventogenesis in Continuous Culture and Presentation of a Model for Shift Induction. Appl Environ Microbiol 1992, 58:3896-3902.

32. Monot $\mathrm{F}$, Engasser JM, Petitdemange $\mathrm{H}$ : Influence of $\mathrm{pH}$ and undissociated butyric acid on the production of acetone and butanol in batch cultures of Clostridium acetobutylicum. Appl Microbiol Biotechnol 1984, 19:422-426. 
33. Fischer CR, Klein-Marcuschamer D, Stephanopoulos G: Selection and optimization of microbial hosts for biofuels production. Metab Eng 2008, 10:295-304.

34. Kreuzer P, Gartner D, Allmansberger R, Hillen W: Identification and Sequence-Analysis of the Bacillus-Subtilis W23 Xylr Gene and Xyl Operator. J Bacteriol 1989, 171:3840-3845.

35. Rodionov DA, Mironov AA, Gelfand MS: Transcriptional regulation of pentose utilisation systems in the Bacillus/Clostridium group of bacteria. FEMS Microbiol Lett 2001, 205:305-314.

36. Lee SF, Forsberg CW, Gibbins LN: Xylanolytic Activity of Clostridium acetobutylicum. Appl Environ Microbiol 1985, 50:1068-1076.

37. Ali MK, Rudolph FB, Bennett GN: Characterization of thermostable Xyn10A enzyme from mesophilic Clostridium acetobutylicum ATCC 824. J Ind Microbiol Biotechnol 2005, 32:12-18.

38. Kraus A, Hillen W: Analysis of CcpA mutations defective in carbon catabolite repression in Bacillus megaterium. FEMS Microbiol Lett 1997, 153:221-226.

39. Chauvaux S: CcpA and HPr(ser-P): mediators of catabolite repression in Bacillus subtilis. Res Microbiol 1996, 147:518-522.

40. Jones SW, Paredes CJ, Tracy B, Cheng N, Sillers R, Senger RS, Papoutsakis ET: The transcriptional program underlying the physiology of clostridial sporulation. Genome Biol 2008, 9:R114.

41. Ni NT, Li MY, Wang JF, Wang BH: Inhibitors and Antagonists of Bacterial Quorum Sensing. Med Res Rev 2009, 29:65-124.

42. Ohtani K, Yuan Y, Hassan S, Wang R, Wang Y, Shimizu T: Virulence Gene Regulation by the agr System in Clostridium perfringens. J Bacteriol 2009, 191:3919-3927.

43. Winzer K: Quorum sensing in solventogenic clostridia. BBSRC China partnering award workshop on improving biobutanol production by solventogenic clostridia Shanghai China; 2009.

44. Wiesenborn DP, Rudolph FB, Papoutsakis ET: Thiolase from Clostridium acetobutylicum ATCC 824 and Its Role in the Synthesis of Acids and Solvents. Appl Environ Microbiol 1988, 54:2717-2722.

45. Zhang Y, Garcia MJ, Lathigra R, Allen B, Moreno C, Vanembden JDA, Young D: Alterations in the Superoxide-Dismutase Gene of an IsoniazidResistant Strain of Mycobacterium tuberculosis. Infect Immun 1992, 60:2160-2165.

46. Gordon D, Abajian C, Green P: Consed: A graphical tool for sequence finishing. Genome Res 1998, 8:195-202.

47. Guo FB, Zhang CT: ZCURVE_V: a new self-training system for recognizing protein-coding genes in viral and phage genomes. BMC Bioinformatics 2006, 7:9.

48. Lowe TM, Eddy SR: tRNAscan-SE: A program for improved detection of transfer RNA genes in genomic sequence. Nucleic Acids Res 1997, 25:955-964.

49. Ghai R, Hain T, Chakraborty T: GenomeViz: visualizing microbial genomes. BMC Bioinformatics 2004, 5:198.

50. Wang SY, Shen XY, Wu CY, Pan F, Shen YY, Sheng HH, Chen XM, Gao HJ: Analysis of whole genomic expression profiles of Helicobacter pylori related chronic atrophic gastritis with IL-1B-31CC/-511TT genotypes. Digest Dis 2009, 10:99-106.

51. Eisen MB, Spellman PT, Brown PO, Botstein D: Cluster analysis and display of genome-wide expression patterns. Proc Natl Acad Sci USA 1998, 95:14863-14868

52. Mermelstein LD, Papoutsakis ET: In vivo methylation in Escherichia coli by the Bacillus subtilis phage Ф3Т I methyltransferase to protect plasmids from restriction upon transformation of Clostridium acetobutylicum ATCC 824. Appl Environ Microbiol 1993, 59:1077-1081.

53. Annous BA, Blaschek HP: Regulation and localization of amylolytic enzymes in Clostridium acetobutylicum ATCC 824. Appl Environ Microbiol 1990, 56:2559-2561.

54. Tao YZ, He YL, Wu YQ, Liu FH, Li XF, Zong WM, Zhou ZH: Characteristics of a new photosynthetic bacterial strain for hydrogen production and its application in wastewater treatment. Int J Hydrogen Energy 2008, 33:963-973.

doi:10.1186/1471-2164-12-93

Cite this article as: Hu et al:: Comparative genomic and transcriptomic analysis revealed genetic characteristics related to solvent formation and xylose utilization in Clostridium acetobutylicum EA 2018. BMC Genomics 2011 12:93.

\section{Submit your next manuscript to BioMed Central and take full advantage of:}

- Convenient online submission

- Thorough peer review

- No space constraints or color figure charges

- Immediate publication on acceptance

- Inclusion in PubMed, CAS, Scopus and Google Scholar

- Research which is freely available for redistribution 